REVIEW

\title{
Pregnancy and pituitary disorders
}

\author{
Z Karaca, F Tanriverdi, K Unluhizarci and F Kelestimur \\ Department of Endocrinology, Erciyes University Medical School, 38039 Kayseri, Turkey \\ (Correspondence should be addressed to F Kelestimur; Email: fktimur@erciyes.edu.tr)
}

\begin{abstract}
Major hormonal changes emerge during pregnancy. The pituitary gland is one of the most affected organs with altered anatomy and physiology. The pituitary gland is enlarged as a result of lactotroph hyperplasia. Due to physiological changes in the pituitary and target hormone levels, binding globulins, and placental hormones, hormonal evaluation becomes more complex in pregnant women. As a consequence of physiological hormonal changes, the evaluation of pituitary functions in pregnant women is quite different from that done in the prepregnant state. Pituitary adenomas may cause problems by their hormone secretion that affects the mother and the fetus besides causing an increased risk of tumor growth. Furthermore, diagnosis, course, and treatment of pituitary diseases point out differences. The changes in anatomy and physiology of the pituitary gland during pregnancy are reviewed. Pituitary disorders namely Cushing's disease; acromegaly; prolactinoma; TSH-secreting, gonadotropin-producing, and clinically nonfunctioning adenomas; craniopharyngioma; and Sheehan's syndrome, which is one of the most common causes of hypopituitarism, lymphocytic hypophysitis, and hypopituitarism, in relation to pregnancy are discussed. Being aware of all this information will prevent any serious problems which mother and child will be exposed to.
\end{abstract}

European Journal of Endocrinology 162 453-475

\section{Introduction}

Pregnancy might be accepted as a new physiological state for the pituitary gland with altered anatomy, modified courses, diagnosis, and treatment of pituitary diseases. This review summarizes the changes in the pituitary gland during normal pregnancy, the placenta as a source of new hormones, and pituitary disorders during pregnancy.

\section{Anatomical changes in the pituitary gland during pregnancy}

The size and shape of the pituitary depend on the sella turcica; therefore, there is considerable variability in its contour (1). During the first two decades of life, it grows rapidly and, in adults, the size of the pituitary gland measures $\sim 10 \mathrm{~mm}$ in length, $5-10 \mathrm{~mm}$ in height, and $10-15 \mathrm{~mm}$ in width. After the fourth decade, considerable interstitial fibrosis occurs and the gland loses weight throughout the rest of life $(2,3)$. Women of childbearing age tend to have larger glands, and upward convexity of the pituitary gland is also seen more frequently in this age and sex group.

There is considerable evidence regarding the enlargement of the pituitary gland during pregnancy. Comte first showed the enlargement of the pituitary gland in pregnant women in the 19th century (4), which was confirmed by other autopsy studies $(5,6)$. In vivo studies also demonstrated increased pituitary volume. The pituitary gland size was found to be increased in three dimensions with an overall increase of $136 \%$ when compared to the control group. This increment was $45 \%$ in the first trimester (7). Pituitary volumes during pregnancy were found to be increased 120\% compared to the control in another study (8). The highest pituitary volumes and widths of the infundibulum were observed during the first three postpartum days. The mean height of the pituitary glands during the postpartum period was found to be $9.3 \mathrm{~mm}$, which was significantly higher than that during the last half of pregnancy. The upper limit for the height of the normal pituitary gland was suggested as $9.6-10 \mathrm{~mm}$ for the gestational period and as $10.2-12 \mathrm{~mm}$ for the immediate postpartum period. The height of the gland correlated best with the gestational age, and the mean height of the gland was $8.8 \mathrm{~mm}$ in the third trimester. The pituitary glands were demonstrated to gain their normal size, shape, and volume within 6 months postpartum $(8,9)$. The height of the pituitary gland seems to be a good measure for the demonstration of the increased size.

The differential diagnosis of pituitary gland enlargement is difficult in pregnant women since magnetic resonance imaging (MRI) is not specific enough. 
Previous pituitary adenoma, pituitary apoplexy or hemorrhagic necrosis of an adenoma, acute Sheehan's syndrome (SS), and lymphocytic hypophysitis (LyH) should be kept in mind in a differential diagnosis. Asymmetrical enlargement and deviation of the stalk, which are not seen during physiological enlargement of the pituitary gland, may indicate the presence of an adenoma. Pituitary height that is higher than $9-10 \mathrm{~mm}$ during pregnancy may arouse suspicion of a pathological reason (10). Compression of optic chiasma and visual field loss were reported in a few cases in the literature (11-13). Thus, pituitary gland lesions should be evaluated carefully in pregnant women with headaches and visual problems. Surgical intervention is usually not required unless there is a suspicion of pituitary adenoma or apoplexy on MRI causing compressive signs.

MRI without i.v. contrast injection seems to be safe during pregnancy, but all FDA-approved Gd chelates belong to 'Pregnancy Category C'. Although diverse effects of these contrast agents with increased dosage and exposure time were reported in animals, the effect of a single clinical dose of $\mathrm{Gd}$ in humans is not well known $(14,15)$. Studies with magnevist (gadopentetic dimeglumine) and omniscan (gadodiamide) for the evaluation of nonpregnancy-related pathologies carried out on pregnant women did not reveal any adverse effects (16-19). The rational approach for pregnant patients is to consider postponing MRI after birth. If not possible, MRI without a contrast agent should be the choice. MRI with a contrast agent after the first trimester of pregnancy should be reserved for cases which require definitive diagnosis that may have serious outcomes for the fetus or the mother.

\section{Physiological changes of pituitary hormone axes during pregnancy}

\section{Hypothalamic-pituitary-adrenal axis}

Although the corticotroph number is unaltered, normal gestation is associated with increased maternal hypothalamic-pituitary-adrenal axis (HPA) axis activity (Table 1 and Fig. 1). Urinary free cortisol (UFC), plasma 17-hydroxycorticosteroids, total and free plasma cortisol, and corticosteroid-binding globulin (CBG) levels are all elevated (20-22). As hepatic CBG production increases under the effect of placental estrogen, free cortisol levels drop transiently and increase ACTH stimulation to maintain a normal free cortisol level. But it is also shown that free cortisol levels start to increase by the 11th week of gestation, and higher levels are observed in the second trimester and they reach a plateau in the third trimester of pregnancy $(21,23)$. There are different explanations for the increased free cortisol levels in pregnancy: resistance to cortisol action, antiglucocorticoid effects of elevated progesterone, altered set point for pituitary ACTH, and autonomic secretion of ACTH from the placenta $(21,24,25)$. The circadian rhythm of cortisol is usually preserved, but it may also be partially blunted $(20,26,27)$.

The placental 11ß-hydroxysteroid dehydrogenase (11ß-HSD 2), which is located in syncytial trophoblastic cells, inactivates active glucocorticoids, cortisol, and corticosterone, which protects the fetus from maternal hypercortisolism (28). Dexamethasone can cross the placenta, which is a poor substrate for $11 \beta$-HSD 2 (29). In normal subjects, conversion of cortisol to cortisone predominates, but in late gestation, the enzyme activity favors the production of the active

Table 1 Summary of changes in anterior pituitary hormones during pregnancy.

\begin{tabular}{|c|c|c|c|c|c|}
\hline $\begin{array}{l}\text { Number of } \\
\text { pituitary cells }\end{array}$ & $\begin{array}{l}\text { Pituitary } \\
\text { hormones }\end{array}$ & $\begin{array}{l}\text { Source of } \\
\text { hormones }\end{array}$ & $\begin{array}{l}\text { Hypothalamic and } \\
\text { placental factors } \\
\text { affecting pituitary }\end{array}$ & Target hormone & $\begin{array}{l}\text { Binding } \\
\text { proteins/ } \\
\text { metabolites }\end{array}$ \\
\hline $\begin{array}{l}\text { Corticotrophs } \\
\text { unaltered }\end{array}$ & $\mathrm{ACTH} \uparrow$ & $\begin{array}{l}\text { Pituitary } \\
\text { Fetoplacental } \\
\text { unit }\end{array}$ & $\begin{array}{l}\text { Hypothalamic CRH } \\
\text { Placental CRH } \\
\text { (stimulate maternal } \\
\text { pituitary (?) ACTH/ } \\
\text { fetoplacental unit ACTH) }\end{array}$ & $\begin{array}{l}\text { Free cortisol } \uparrow \\
\text { Bound cortisol } \uparrow\end{array}$ & $\begin{array}{l}\mathrm{CBG} \uparrow \\
\mathrm{CRH}-\mathrm{BG} \uparrow \\
\text { Urinary cortisol } \\
\quad \text { metabolites } \uparrow\end{array}$ \\
\hline Somatotrophs $\downarrow$ & $\mathrm{GH} \downarrow$ & $\begin{array}{l}\text { Pituitary GH } \\
\text { suppressed } \\
\text { GH-V } \uparrow\end{array}$ & $\begin{array}{l}\text { Hypothalamic GHRH } \\
\text { Placental GHRH (stimulate } \\
\text { pituitary GH/no effect } \\
\text { on } \mathrm{GH}-\mathrm{V} \text { ) }\end{array}$ & $\begin{array}{l}\text { IGF1 slightly } \uparrow \\
\text { IGF1 also } \\
\text { produced from } \\
\text { placenta }\end{array}$ & $\mathrm{GHBP} \uparrow$ \\
\hline Lactotrophs $\uparrow$ & $\mathrm{PRL} \uparrow$ & $\begin{array}{l}\text { Pituitary } \\
\text { Decidua }\end{array}$ & $\begin{array}{l}\text { Hypothalamic dopamine } \\
\text { (inhibits pituitary PRL/no } \\
\text { effect on decidual PRL) }\end{array}$ & & \\
\hline Gonadotrophs $\downarrow$ & $\mathrm{FSH}, \mathrm{LH} \downarrow$ & $\begin{array}{l}\text { Decreased due to } \\
\text { increased sex } \\
\text { steroids }\end{array}$ & $\begin{array}{l}\text { GnRH (gonadotropin } \\
\text { response to GnRH } \\
\text { is decreased) }\end{array}$ & $\begin{array}{l}\text { Estrogen } \uparrow \\
\text { Progesterone } \uparrow \\
\quad \text { (from placenta) }\end{array}$ & $\mathrm{SHBG} \uparrow$ \\
\hline $\begin{array}{c}\text { Thyrotrophs } \\
\text { unaltered }\end{array}$ & $\begin{array}{l}\text { TSH decreased in } \\
\text { the first trimester }\end{array}$ & $\begin{array}{l}\text { Decreased due to } \\
\text { similarity of TSH } \\
\text { with hCG }\end{array}$ & $\begin{array}{l}\text { TRH (response is } \\
\text { preserved) }\end{array}$ & $\begin{array}{l}\mathrm{T}_{4} \text { (total and free } \\
\left.\mathrm{T}_{4}\right) \uparrow \text { in the first } \\
\text { trimester }\end{array}$ & TBG $\uparrow$ \\
\hline
\end{tabular}




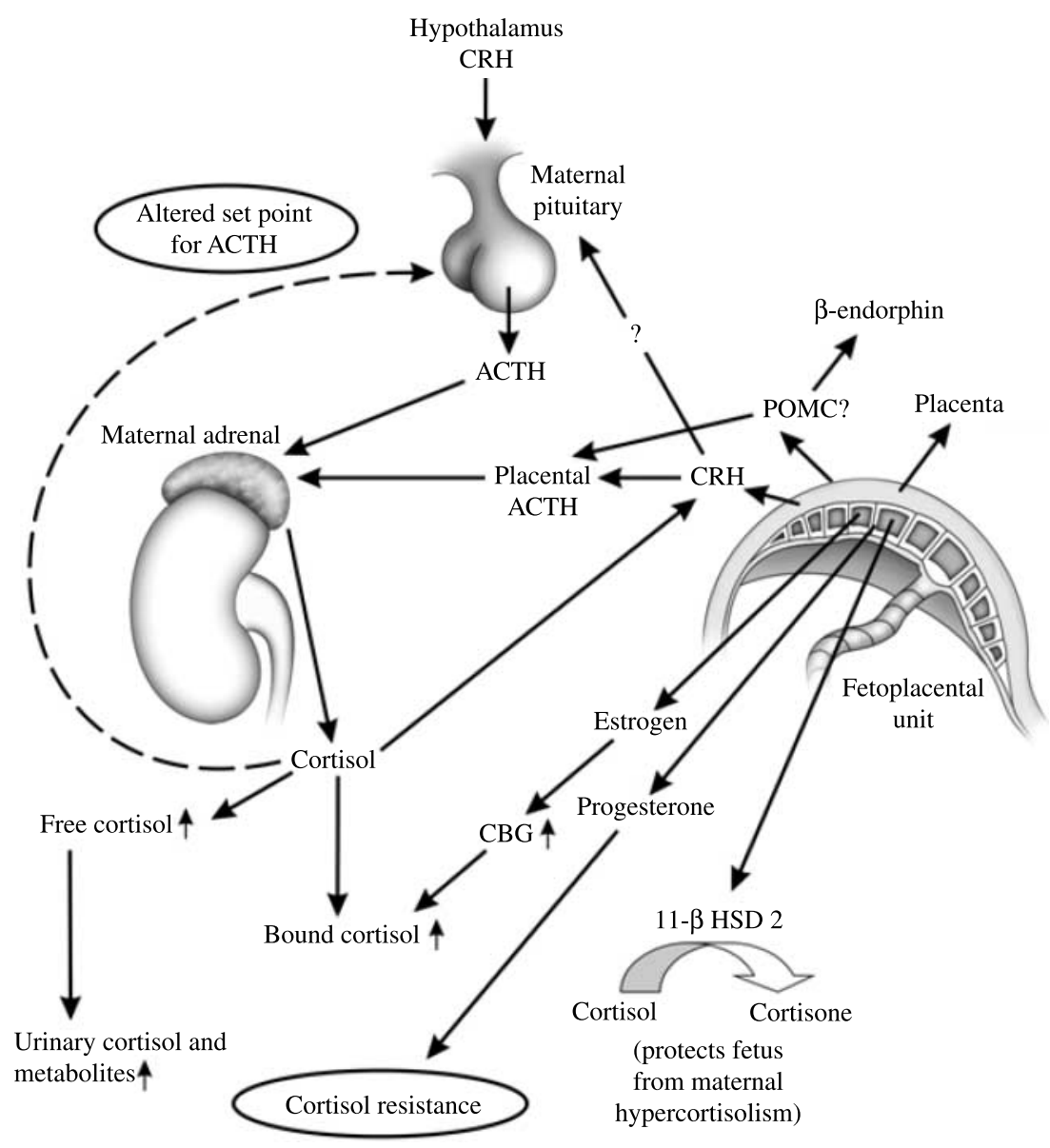

Figure 1 HPA axis during pregnancy: hypothalamic $\mathrm{CRH}$ stimulates maternal ACTH secretion, which in turn stimulates adrenal cortisol secretion. Placental $\mathrm{CRH}$ is an important stimulator of fetoplacental unit ACTH which contributes to increased adrenal cortisol secretion. The effect of placental $\mathrm{CRH}$ on maternal pituitary is unclear. There is a positive feed-forward effect between $\mathrm{CRH}$ and cortisol. Estrogen increases CBG, though total cortisol is increased, but free cortisol secretion is also increased during pregnancy. Progesterone has antiglucocorticoid effects in the mother and 11 $\beta$-HSD 2 protects the fetus from maternal hypercortisolism (-, stimulation; - - -, inhibition; $\mathrm{CRH}$, corticotropin-releasing hormone; ACTH; POMC, proopiomelanocortin; CBG, corticosteroid-binding globulin; 11 $\beta$-HSD 2, 11ß-hydroxysteroid dehydrogenase 2). hormone which is important for fetal lung maturation (30). Corticosterone and immunoreactive ACTH were found to have circadian variation throughout and during early pregnancy respectively in pregnant rats (31).

Plasma ACTH levels increase throughout pregnancy reaching maximum levels during labor. Demura et al. showed the presence of ACTH and $\beta$-endorphin in trophoblastic tissues, suggesting a common origin, probably proopiomelanocortin (32). The elevation of ACTH in late pregnancy suggests a source which is not subject to normal feedback control (20). Placental ACTH is shown to be regulated by corticotropinreleasing hormone (CRH) (33).

The placenta is the source of elevated CRH during gestation (34). Placental CRH is similar to hypothalamic CRH in structure, immunoreactivity, bioactivity, and transcriptional sites. Although the circadian rhythms of ACTH and cortisol are preserved, the circadian rhythm of CRH could not be demonstrated; therefore, a noncircadian, nonpulsatile stimulation of maternal HPA axis by placental CRH is assumed (26). There seems to be a positive feed-forward effect of CRH and glucocorticoids. Placental CRH is stimulated by glucocorticoids, which explains the rise in $\mathrm{CRH}$ preceding parturition $(35,36)$. CRH stimulates ACTH release from the placenta in a paracrine fashion besides stimulating the maternal pituitary, although the latter source is not exactly proven (37). Systemic maternal effects of CRH are thought to be limited due to CRHbinding globulin (CRH-BG). CRH-BG levels decrease in the last few weeks of pregnancy, which normally inactivates CRH. Thus, biologically active CRH is increased (38).

Although maternal corticotrophs are desensitized, HPA axis function remains intact in normal pregnancy. Placental CRH appears to be the major stimulus for the HPA axis in the third trimester $(28,38)$. CRH receptors are present in reproductive tissues such as the placenta and endometrium besides CNS, heart, lung, skeletal muscles, and lymphatic organs (39). CRH is important for decidualization, implantation, and ovarian function. Placental $\mathrm{CRH}$ is important for fetal adrenal steroidogenesis, maintenance of fetoplacental circulation, and determination of the onset of parturition (40). 


\section{GH-insulin-like growth factor 1 axis}

Pregnancy is a state of mild physiological acromegaly (41). During early gestation, maternal GH is secreted from the pituitary, which is suppressed in later weeks (Table 1 and Fig. 2). In rat pregnancy, baseline circulating GH level is not affected by ghrelin; therefore, direct alteration of somatotroph function without an increased number of somatotrophs is assumed (42). Placental GH $(\mathrm{GH}-\mathrm{V})$ is detectable by the fifth week of pregnancy, and levels increase exponentially and peak at 35-37 weeks. Individual GH-V levels vary widely with peak levels that range between 4.6 and $69.2 \mathrm{ng} / \mathrm{ml}$ (43). GH-V is secreted continuously, and it is regulated neither by GH-releasing factor nor by ghrelin (44). It binds to hepatic GH receptor with an affinity that is similar to the affinity with which the receptor binds to $\mathrm{GH}$, and it is not detected by routine RIA and IRMA methods (45). GH-V decreases pituitary GH secretion by stimulating insulin-like growth factor 1 (IGF1) $(46,47)$. GH-V and IGFs have growth-promoting effects on the fetus and placenta (41). Most of the GH-V is cleared from plasma $30 \mathrm{~min}$ after delivery and is not detectable in the fetal circulation (48). Decreased GH response to insulin-induced hypoglycemia or arginine suggests decreased reserve of $\mathrm{GH}$ secretion by the maternal pituitary $(49,50)$.

\section{Prolactin axis}

The enlargement of the pituitary gland is explained by massive hyperplasia of lactotrophs and their transformation to pregnancy cells. The pregnancy cells are morphologically modified prolactin (PRL)-producing cells derived from the preexisting mature lactotrophs (6) (Table 1). During pregnancy, maternal PRL levels increase by tenfold parallel to estrogen increases (51) (Fig. 3). Progesterone also stimulates PRL secretion (52). Maternal PRL originates from the maternal pituitary with small contributions from the decidua and fetal pituitary. Maternal decidua is responsible for increased PRL levels in the amniotic fluid (53). Maternal pituitary PRL secretion is stimulated by thyrotropin-releasing hormone (TRH), arginine, meals, and sleep as in nonpregnant women (54). Increased PRL secretion during pregnancy is important for the preparation of breast tissue for lactation, but the role of PRL in amniotic fluid is unknown.

Pregnancy induces long-term changes in PRL secretion. Pregnancy suppresses the secretion of PRL by the maternal pituitary permanently $(55,56)$.

Big big PRL is reported in a range of $8-38 \%$ of total PRL during pregnancy (57-59). Frequency of macroprolactinemia during pregnancy is reported as $2.9-3.8 \%$ due to anti-PRL autoantibodies $(60,61)$. Macroprolactinemia persists during pregnancy, and the PRL increment in macroprolactinemic women is less than that in normal pregnant women (62).

\section{TRH-TSH axis}

Although the appearance and distribution of thyrotropic cells are preserved, thyrotropin (TSH) secretion is altered during pregnancy (Table 1). The biochemical similarity of TSH and human chorionic gonadotropin (hCG) results in decreased maternal TSH levels, particularly in 9-13 weeks of gestation, when hCG production by the placenta is highest (63) (Fig. 4).

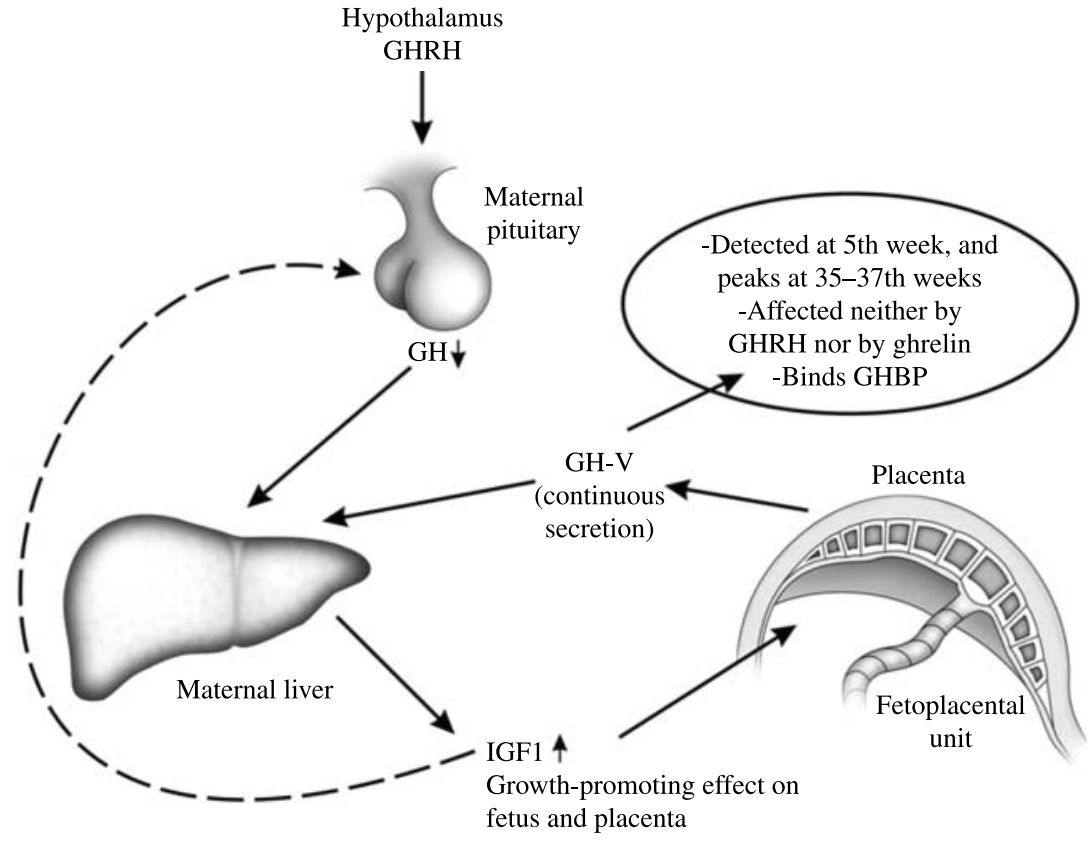

Figure 2 GH-IGF1 axis during pregnancy: the placenta secretes a variant of $\mathrm{GH}$, which replaces pituitary GH for stimulating IGF1 production from the liver. Increased IGF1 inhibits pituitary $\mathrm{GH}$ secretion. (-, stimulation; - - - inhibition; GH; GH-V, GH variant; IGF1; insulin-like growth factor 1). 


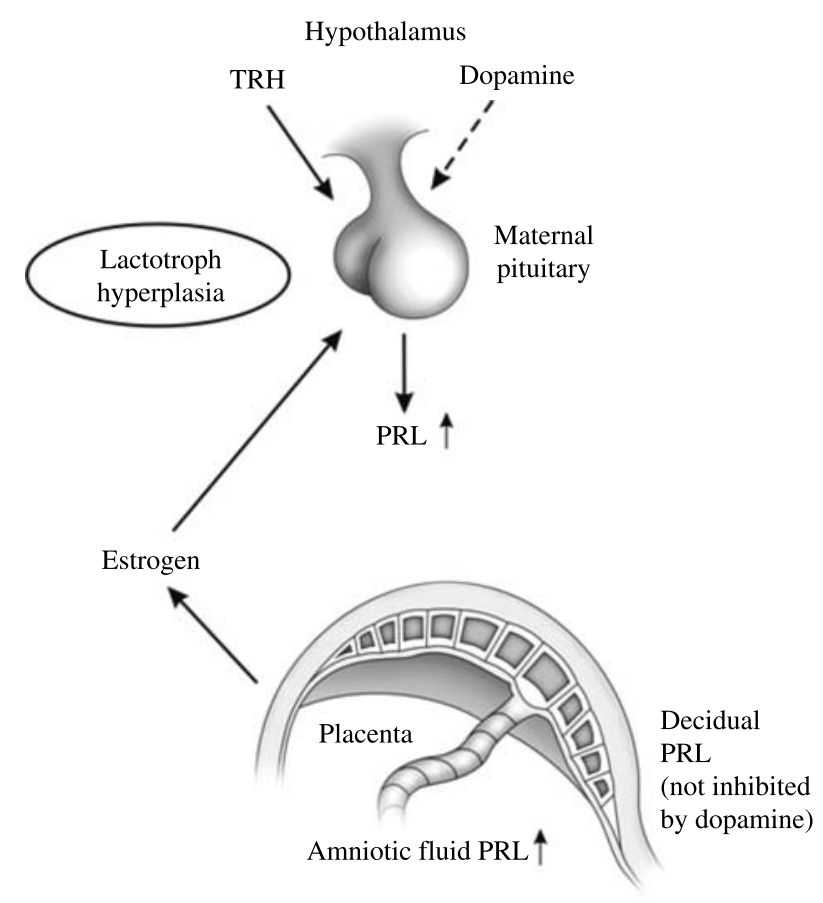

Figure 3 PRL axis during pregnancy: maternal PRL is increased during pregnancy due to estrogen-stimulated lactotroph hyperplasia with small contributions from decidual PRL. Maternal decidua is responsible for increased PRL in amniotic fluid. Unlike pituitary PRL, decidual $P R L$ is not affected by TRH and dopamine. (一, stimulation; - - -, inhibition; $\mathrm{TRH}$, thyrotropin-releasing hormone; $\mathrm{T}_{4}$, thyroxine; TBG, thyroxine-binding globulin; hCG, human chorionic gonadotropin; PRL, prolactin).

Additionally, increased estrogen levels lead to a significant increase in thyroxine $\left(\mathrm{T}_{4}\right)$-binding globulin (TBG) levels that reach a plateau after 12-14 weeks of gestation, and total thyroid hormone levels are concomitantly increased (64). There is a slight increase in serum concentrations of free $\mathrm{T}_{4}$ during the first trimester, and they then decrease, but these changes are minimal and serum levels of free $\mathrm{T}_{4}$ usually remain within the normal ranges for nonpregnant women (65). There is also a study which measured free tri-iodothyronine and free $\mathrm{T}_{4}$ levels in women at term using ten different commercially available kits, which revealed that free thyroid hormones are always significantly lower than those in nonpregnant women (66). The negative-feedback control of TSH is intact during pregnancy, and TSH concentrations are usually similar to those in nonpregnant women $(63,67,68)$.

There is an increased requirement of $\mathrm{T}_{4}$ during pregnancy, which is sustained until delivery (69). Therefore, the increased serum TBG cannot be the sole explanation for the increased demand for $\mathrm{T}_{4}$. The increased requirement is also attributed to the placental degradation of $\mathrm{T}_{4}$, transfer of $\mathrm{T}_{4}$ from mother to fetus, and increased maternal clearance of $\mathrm{T}_{4}(64)$.

\section{Gonadotropin axis}

Gonadotropic cells show decreased immunoreactivity for LH during pregnancy, which is fully established at 6 months and returns to normal at postpartum 11th month (6) (Table 1). Maternal serum gonadotropins start to decrease by $6-7$ weeks of pregnancy and become undetectable in the second trimester. Pituitary FSH and LH synthesis are suppressed due to elevated sex steroids (17- $\beta$-estradiol and progesterone) and regulatory peptides (inhibin) during pregnancy (54). FSH and LH responses to GnRH stimulation are also decreased (70).

\section{Posterior pituitary}

Pregnancy is associated with a lowering of the set point for serum osmolality by about $10 \mathrm{mOsm} / \mathrm{kg}$. The decrease starts by the first missed menstrual period and gradually decreases until the tenth week of gestation, which does not change later on (71). Serum sodium is decreased by about $4-5 \mathrm{mEq} / \mathrm{ml}$ due to this reset osmostat. On the other hand, placental vasopressinase is associated with increased vasopressin (AVP) degradation, which may unmask borderline diabetes insipidus (DI) or worsen DI during pregnancy (72).

The majority of DI cases (58\%) deteriorate, 20\% improve, and $15 \%$ remain the same during pregnancy. The increased glomerular filtration rate, which increases the requirement of AVP; changes in tubular sensitivity to AVP; degradation by the enzyme

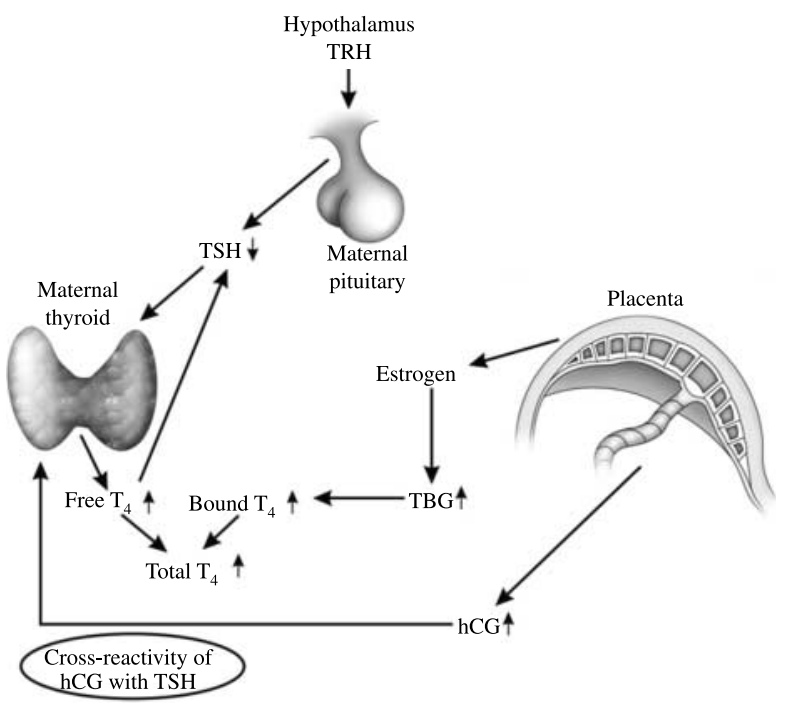

Figure $4 \mathrm{TRH}-$ thyrotropin axis during pregnancy: due to the similarity of hCG with TSH, TSH level is decreased in the first trimester of pregnancy with a slight increase in free $T_{4}$, but after the first trimester, free thyroid hormones usually remain within the normal ranges. Estrogen increases TBG levels, which leads to an elevation in total $\mathrm{T}_{4}$ levels. ( - , stimulation; - - -, inhibition; $\mathrm{TRH}$, thyrotropin-releasing hormone; $\mathrm{T}_{4}$, thyroxine; TBG, thyroxine-binding globulin; hCG, human chorionic gonadotropin; PRL, prolactin). 
vasopressinase; effects of increased glucocorticoids, progesterone, and $\mathrm{T}_{4}$ on AVP; and the possible compression of posterior pituitary were thought to be responsible for the different effects of pregnancy on the progression of DI. In clinical practice, lactation may improve or may not change the course of DI (73).

\section{Pituitary disorders and pregnancy}

\section{Cushing's disease and pregnancy}

Pregnancy is rare in patients with Cushing's syndrome (CS) because of hypercortisolemia, hyperandrogenemia, and/or hyperprolactinemia, leading to impaired fertility $(74,75)$. The etiologies of CS are similar to those found in nonpregnant women in pregnancy, but benign adrenal tumors are the most frequent cause in contrast to nonpregnant patients. It is probably because of aberrant adrenal receptors for LH and hCG. Half of the reported gestational CS cases have adrenal causes, and about $40 \%$ are Cushing's disease (CD) $(28,76,77)$. Cyclical CD due to an ACTH-producing pituitary adenoma with fluctuating ACTH levels was also reported (78).

Maternal and fetal morbidities are increased in pregnant women with CS. Gestational diabetes, hypertension, preeclampsia, eclampsia, congestive heart failure, and pulmonary edema are all related to these morbidities. Fetal loss such as spontaneous abortions, stillbirths, and early neonatal deaths are increased (79) besides premature birth in almost half of the cases $(76,80)$.

Diagnosis of Cushing's syndrome during pregnancy CS may be detected before or during pregnancy. The cases which are diagnosed during gestation have similarities to normal pregnancy such as weight gain, hypertension, glucose intolerance, and striae. In normal pregnancy, the striae are usually white in contrast to large purple striae in CS. Hirsutism and acne may indicate excessive androgen production during pregnancy. The presence of hypokalemia, muscle weakness, pathological fractures, and large purple abdominal striae are important clues for CS $(81,82)$. Diagnostic tests for CS become less reliable during gestation. Lowdose dexamethasone administration usually fails to suppress cortisol secretion during pregnancy, suggesting a reset of maternal feedback set point. Mean cortisol levels ranging from $4 \mu \mathrm{g} / \mathrm{dl}$ in the first trimester to more than $20 \mu \mathrm{g} / \mathrm{dl}$ in the second and third trimesters after low-dose dexamethasone administration are reported in the literature (83). According to the guidelines of diagnosis of CS, the use of a dexamethasone suppression test should not be preferred because of false positive results during pregnancy due to blunted response to dexamethasone (84).

Late-night cortisol $<7.5$ or $5 \mu \mathrm{g} / \mathrm{dl}$ or $50 \%$ of morning levels are considered to be normal, which can also be applied to pregnant patients. Since serum cortisol circadian variation is preserved during pregnancy, loss of circadian rhythm might be a clue for $\mathrm{CS}$, but the nadir level for late-midnight cortisol is higher than that in the nonpregnant state. UFC has been suggested as the best choice for screening of CS during pregnancy (84). UFC levels are unchanged during the first trimester, but levels may be increased up to threefold in the second and third trimesters (20). UFC greater than three times the upper limit should be taken into consideration in the last two trimesters (84). The role of salivary cortisol for the diagnosis of CS during pregnancy needs to be determined.

Plasma ACTH levels can be used for differential diagnosis of ACTH- and nonACTH-dependent CS, taking into account the predominance of adrenal etiology and the physiological increase of ACTH during gestation (85). ACTH levels may not be suppressed in pregnant patients with adrenal CS, unlike in nonpregnant ones. This may be attributed to the production of ACTH by the placenta or stimulation of ACTH by placental CRH. Detectable ACTH levels may not exclude adrenal etiology.

A high-dose dexamethasone suppression test for distinction of CD and ectopic ACTH may be helpful. The HPA axis becomes resistant in the third trimester of pregnancy, and higher doses of CRH $(2 \mu \mathrm{g} / \mathrm{kg})$ are needed to evoke sufficient ACTH and cortisol response $(28,86$, $87)$. CRH stimulation by $100 \mu \mathrm{g}$ causes an increase in ACTH and cortisol in pregnant patients with CD (88).

Inferior petrosal sinus sampling should not be a routine investigation method because of radiation exposure and increased thrombotic events, although it has been used in a few pregnant patients with suspected CD. The direct jugular approach should be preferred to minimize radiation to the fetus $(28,88-90)$.

If $\mathrm{CD}$ is suspected, imaging studies can be used to localize the adenoma, but unfortunately CD is usually caused by a microadenoma, and the growth of the pituitary gland during normal pregnancy can mask the visualization of the microadenomas. Adrenal computerized tomography (CT) scans should be avoided, and pituitary MRI should be reserved for patients for whom pituitary surgery is planned (85).

\section{Treatment of Cushing's disease during pregnancy} Pregnancy may influence the course of CS in different ways, either exacerbating or ameliorating the disease (76, 79, 80, 91, 92). Unregulated placental CRH may be the cause of exacerbating hypercortisolemia during pregnancy, and it improves after parturition.

Due to the small number of reported pregnant women with $\mathrm{CD}$, available data are not enough to compare the outcome of treated and untreated patients. While making a decision about treatment, the severity of hypercortisolemia and the stage of gestation are important factors. Treatment of CS may be considered if the increased fetal loss rates and premature labor are taken into account $(91,93)$. Early diagnosis and treatment of the disease are important to improve the outcome of both the fetus and the mother. Treatment of 
choice for ACTH-secreting adenomas is transsphenoidal surgery, which has been performed successfully during the second trimester of pregnancy $(28,88,92,94)$. Radiotherapy is normally contraindicated during gestation, but pregnancy shortly after treatment by gamma-knife for CD with normal gestational course, despite high disease activity, is reported (95).

In severe CS, when surgery cannot be performed and the term is not close, medical treatment can be considered. Ketoconazole, metyrapone, and mitotane are the agents used in medical treatment of CS. Ketoconazole has been used in CS during pregnancy without untoward effects $(28,81,96-98)$. Although metyrapone may cause adrenal insufficiency in the neonate, it has been used during pregnancy but not always with symptom control (99-104). Lindsay et al. reported 20 women receiving medical therapy (11 patients metyrapone; 3, ketoconazole; 3, cyproheptadine; 1 , aminoglutethimide; and 2 , mitotane) for CS usually starting in the second or third trimester (28). Eighteen of the patients had live births, and two infants whose mothers were treated with metyrapone died (99, 101). Intrauterine growth retardation, fetal hypoadrenalism and coarctation of aorta with metyrapone, and transient neonatal hypoglycemia with ketoconazole were reported in individual cases $(28,81,100,104)$. Mitotane during pregnancy is teratogenic and requires therapeutic abortion (105). If medical treatment is considered, metyrapone is recommended instead of ketoconazole due to its inhibitory effects on androgen synthesis (106).

There are limited data regarding the long-term outcome of $\mathrm{CD}$ following pregnancy, but management of $\mathrm{CD}$ during pregnancy by surgery usually results in remission, and sometimes, subsequent uneventful pregnancies may also occur (28).

Conclusion If $\mathrm{CD}$ is diagnosed during the first trimester, medical therapy should be considered according to the severity of hypercortisolemia until the removal of the tumor in the second trimester. Surgery is the treatment of choice for pregnant women with $\mathrm{CD}$ during the second trimester. For cases with delayed diagnosis late in the third trimester, medical treatment may be preferred, and the surgery may be postponed to the postpartum period. Metyrapone is the drug of choice for medical therapy. Patients treated for CD during pregnancy either by surgery or by medical therapy should be monitored and treated for possible adrenal insufficiency when necessary.

\section{Acromegaly and pregnancy}

Fertility is usually impaired in acromegaly due to altered gonadotropin secretion, which is caused by the destruction of gonadotroph cells or hyperprolactinemia, which occurs in about $40 \%$ acromegalic patients (107), and hyperandrogenemia $(108,109)$. The role of increased $\mathrm{GH}$ and IGF1 on gonadal impairment is less clear.
Diagnosis of acromegaly during pregnancy In pregnant acromegalic patients, pituitary GH secretion is not diminished, and IGF1 increases in the second trimester as in normal pregnancy. To diagnose acromegaly in pregnancy, specific RIAs for GH-V are required to differentiate pituitary and placental secretion of $\mathrm{GH}$ (108). IGF1 levels are less useful in diagnosis and the follow-up of acromegaly during pregnancy since its occurrence is also increased by $\mathrm{GH}-\mathrm{V}$ in normal pregnancy (110). If acromegaly is suspected during pregnancy, definitive diagnosis is difficult, and treatment may be postponed to the postpartum period. The use of an oral glucose tolerance test for suppression of GH during pregnancy is not well established, although it has been used in some of the reports $(108,111,112)$. Increased GH in response to TRH stimulation may also be observed during the course of gestation in acromegalic patients, whereas placental GH does not respond to TRH $(110,113)$. The increased, but highly pulsatile GH levels might be a clue for the diagnosis of acromegaly during pregnancy $(110,114)$.

Limited data are available about pregnancy in acromegaly. The series about acromegaly are summarized in Table 2.

Treatment of acromegaly during pregnancy The major concern about acromegaly during pregnancy is the potential tumor expansion leading to neurological and/or visual complications probably due to the growth-promoting effect of estrogens. Dopamine agonists can control the disease in $10 \%$ of acromegaly cases (115). Bromocriptine has been used in previously treated or untreated acromegalic patients during pregnancy (116-118). The drug will be more effective on tumors with GH and PRL cosecretion. There are no data regarding the use of cabergoline for acromegaly during pregnancy at least according to our knowledge.

Octreotide treatment used throughout pregnancy for different problems, such as nesidioblastosis, TSHsecreting pituitary adenoma, or acromegaly, seems to be feasible and safe (119-122), but octreotide is not registered during pregnancy. Octreotide can cross the placenta, and the receptors demonstrated on the placental membranes of octreotide-treated and untreated pregnant women displayed low affinity for octreotide, which may explain the lack of changes in GH-V and IGF1 concentrations during octreotide treatment (123). Octreotide has been used successfully in acromegalic pregnant patients until confirmation of pregnancy without any deleterious effect on the fetus (112, 124). Maternal-fetal transfer of octreotide has been detected in patients with acromegaly, and TSHsecreting adenoma without any effect on TSH, thyroid hormone, or IGF1 in the newborn $(121,125)$. Lanreotide has also been used in a pregnant woman without any side effects, but it was discontinued after confirmation of pregnancy (126). 


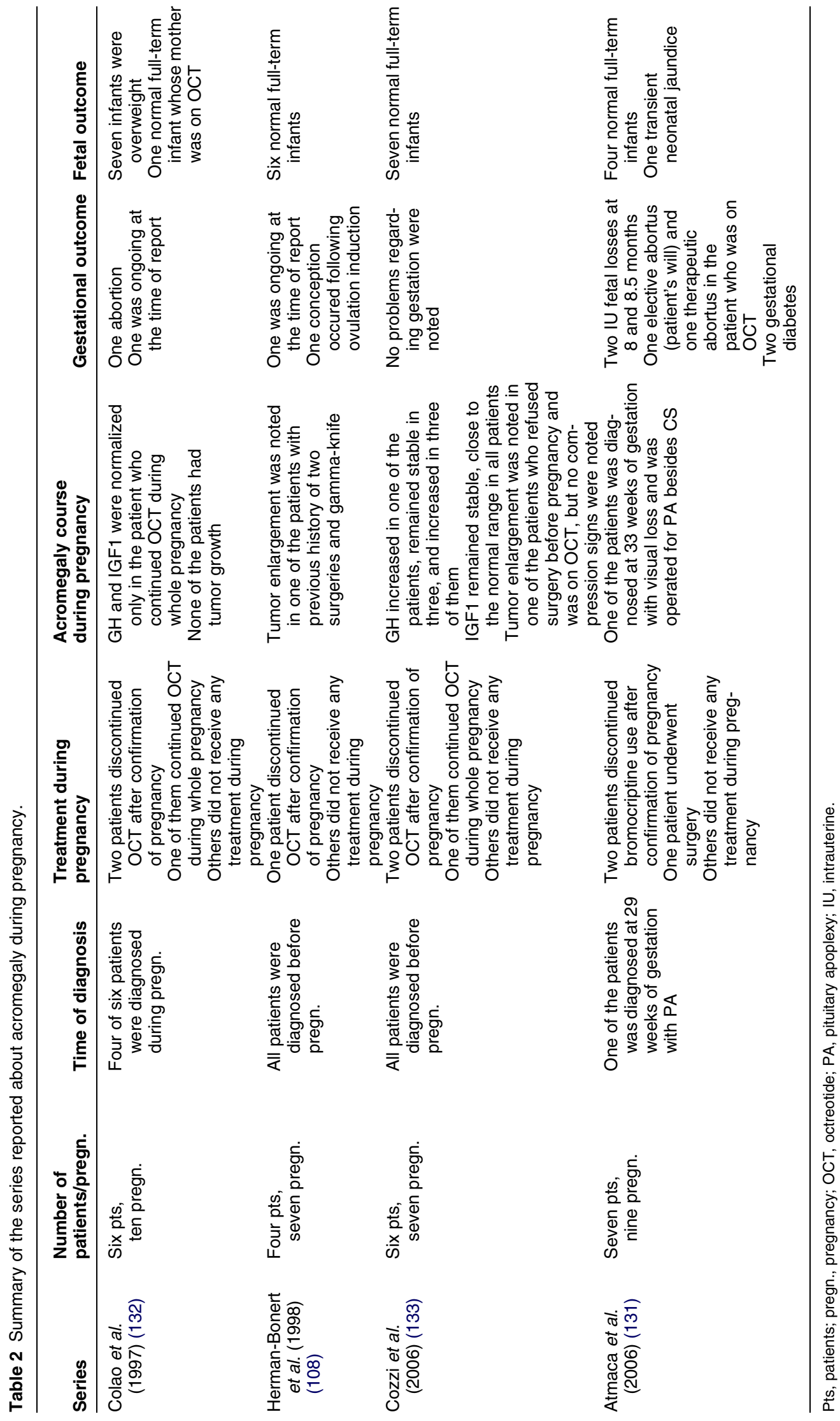


Pegvisomant has been used in two pregnant patients with acromegaly until confirmation of pregnancy without untoward effects. Maternal IGF1 was controlled well, and transplacental passage of the drug was absent or minimal. So the effect on the fetal GH axis is unlikely, and there is no evidence of substantial secretion into breast milk $(127,128)$.

Since acromegaly itself has metabolic and cardiovascular complications, it may affect the mother and the fetus by causing diabetes mellitus, hypertension, and coronary artery disease (129). Pregnancy may lead to improvement of acromegaly as reported in three pregnancies of an acromegalic woman with uncontrolled disease probably due to the blocking effects of estrogen on IGF1 production in the liver. Despite increasing placental GH, IGF1 levels were lower than those in the nonpregnant state close to the normal range (130).

Follow-up of patients with acromegaly after parturition was reported by some authors. Six patients had recurrence shortly after parturition, and two of them were managed with octreotide and radiotherapy, three of them with octreotide, and one with cabergoline only $(108,131)$. Pituitary imaging studies performed after parturition did not reveal any tumor growth (128, $132,133)$.

Conclusion Pregnancy should be considered in acromegalic women with amenorrhea before starting any treatment. If conception is planned, acromegaly should be treated first to prevent the potential growth of a tumor. If acromegaly is diagnosed during pregnancy, octreotide may be used in cases with compressive signs. Interruption of medical therapy during pregnancy is unlikely to affect the long-term outcome of acromegaly if the prolonged course of the disease is considered. Breastfeeding is not contraindicated for acromegalic women with uneventful pregnancies.

\section{Prolactinomas and pregnancy}

Prolactinomas are the most common cause of persistent hyperprolactinemia and account for $50 \%$ of the functioning pituitary tumors (134). After the use of bromocriptine as the first-line treatment in prolactinomas since the 1970 s, pregnancies in patients lacking a previous history of surgery and growth of prolactinoma during gestation have been described. Women with prolactinomas who are on dopamine agonist therapy should be warned about the rapid restoration of fertility, sometimes before resuming the first menses. So when a woman with a PRL-secreting macroadenoma wishes to become pregnant, normalization of serum PRL and significant reduction in tumor volume are necessary in order to prevent the compression of vital structures during pregnancy (135).

In pregnant women with microprolactinomas, dopamine agonists can be stopped safely due to the low risk of clinically relevant tumor expansion $(136,137)$ (Table 3). So patients should be followed up monthly according to clinical symptoms such as headache and visual disturbance. Visual field examinations should be done each trimester. There is no need for periodical imaging of the prolactinoma during pregnancy, and PRL measurement is of little help.

Maximal pituitary proliferation, pituitary tumortransforming gene mRNA, fibroblast and vascular endothelial growth factor expression are found to be increased under the effect of estrogen, and PRL levels and the size of prolactinomas are found to be decreased under the effect of antiestrogen treatment in rats (138). So pregnancy may lead to an increase in prolactinoma size. The risk of tumor growth in pregnant patients with macroprolactinomas is higher than that in those with microprolactinomas. Pregnancy should be avoided in these patients by nonhormonal contraceptive methods until tumor shrinkage occurs. Although the use of

Table 3 Summary of growth of prolactinomas during pregnancy.

\begin{tabular}{|c|c|c|c|}
\hline Series & $\begin{array}{l}\text { Patient number } \\
\text { and characteristics }\end{array}$ & $\begin{array}{l}\text { Symptomatic } \\
\text { tumor growth (\%) }\end{array}$ & $\begin{array}{l}\text { Asymptomatic } \\
\text { tumor growth (\%) }\end{array}$ \\
\hline Molitch (1985) (136) & $\begin{array}{l}\text { Two hundred and forty-six patients with } \\
\text { microprolactinoma without previous } \\
\text { history of surgery or irradiation }\end{array}$ & 1.6 & 4.5 \\
\hline \multirow[t]{2}{*}{ Molitch (1985) (136) } & $\begin{array}{l}\text { Forty-five patients with macroprolactinoma } \\
\text { with previous history of bromocriptine } \\
\text { use before gestation }\end{array}$ & 15.5 & 8.9 \\
\hline & $\begin{array}{l}\text { Forty-six patients with macroprolactinoma } \\
\text { with previous history of surgery or } \\
\text { irradiation before gestation }\end{array}$ & 4.3 & \\
\hline Musolino et al. (2001) (137) & $\begin{array}{l}\text { Seventy-one patients with microprolactinoma } \\
\text { with previous history of bromocriptine } \\
\text { use before gestation }\end{array}$ & 2.4 & 2.4 \\
\hline \multirow[t]{2}{*}{ Musolino et al. (2001) (137) } & $\begin{array}{l}\text { Twenty-one patients with macroprolactinoma } \\
\text { with previous history of bromocriptine } \\
\text { use before gestation }\end{array}$ & 37 & $\begin{array}{l}17.7 \\
\text { (all macroprolactinomas) }\end{array}$ \\
\hline & $\begin{array}{l}\text { Thirty patients with macroprolactinoma with } \\
\text { previous history of surgery before gestation }\end{array}$ & 33 & \\
\hline
\end{tabular}


bromocriptine and cabergoline during gestation does not cause problems, exposure of the fetus to these drugs should be minimized. The first trimester is the period in which teratogenicity from any drug is found most often, and the growth of a macroadenoma is the least. Therefore, it is recommended to stop the drug when pregnancy is confirmed (135). There is an advantage of cabergoline due to its prolonged action, and PRL levels may be suppressed up to 120 days after its withdrawal (139), but it may also be considered as a problem since the intrauterine exposure time of the fetus is increased for an additional one week or more weeks. Quinagolide can be used in hyperprolactinemic patients willing pregnancy until confirmation of pregnancy due to its short life (22 h) (140). Surgery before pregnancy is indicated in patients whose tumor does not respond to dopamine agonists or in those who developed tumor growth in previous gestations (141). The increased duration of treatment with dopamine agonists before conception might be a good prognostic factor for pregnancy (142).

There are two options for pregnant patients with macroprolactinoma. The first is to discontinue the dopamine agonist after confirmation of pregnancy with close follow-up. Monitoring should include screening for symptoms such as headache and visual problems, visual field examination every 2 months, and pituitary MRI without a contrast agent after the first trimester, which can be individualized for each patient. PRL assays may be useful if the levels are decreased in spite of the increasing tumor size, which may indicate apoplexy rather than tumor expansion. Monitorization may be preferable in patients with relatively small macroadenomas away from the optic chiasma. The second option is continuing dopamine agonist therapy throughout pregnancy. The second option may be preferred when the duration of dopamine agonist therapy before conception is short or when the tumor is outside intrasellar boundaries. If clinical signs of progression such as severe headache and visual field defects occur, an MRI without Gd should be performed, and then a dopamine agonist should be restarted if there is an increase in tumor size (143). If there is no response to dopamine agonist therapy, delivery may be the treatment of choice when the term is close. Transsphenoidal surgery can be performed on patients whose term is not close (144). Although good results have been reported with surgery, increased risk of spontaneous abortions should be kept in mind (145).

There is much experience of bromocriptine use during pregnancy. The incidence of abortions, ectopic pregnancies, or congenital malformations is similar in bromocriptine-using mothers and the general population (136, 146-149). One undescended testis and one talipes deformity were reported with the use of bromocriptine throughout gestation (147). Although most of the reported cases received bromocriptine during the first 4 weeks of pregnancy, no teratogenic effects have been demonstrated. Long-term follow-up of 64 children between 6 months and 9 years whose mothers had been treated with bromocriptine showed no adverse effects (150). Bromocriptine is the preferred dopamine agonist for prolactinoma during pregnancy, but since it crosses the placenta, it should not be continued if not necessary (151). Although the number of pregnancies is smaller in the studies, similar results are obtained with cabergoline (139, 152-158). Cabergoline may be an effective and safe alternative to bromocriptine during pregnancy with a good tolerance (159). Since the data regarding pergolide and quinagolide are limited, they should not be used in this setting during pregnancy. Ectopic pregnancy, miscarriages, and fetal malformations were reported during quinagolide usage (160). Morange et al. reported better tolerability and efficacy of quinagolide in pregnant patients with prolactinoma without any congenital abnormalities (161). For medical therapy of prolactinomas, vomiting may be a problem during the first trimester. If vomiting occurs within $2 \mathrm{~h}$ after bromocriptine use, patients may be advised to retake their medication.

The main goal of treatment during pregnancy is to maintain the adenoma away from the optic chiasma. There is no universally accepted target level for PRL. Low levels or levels within the normal range for physiological pregnancy may be the target (162). Despite the evidence that hypoprolactinemia may impair progesterone secretion from corpus luteum, marked hypoprolactinemia which may be caused by dopaminergic agents does not affect the spontaneous abortion rate. The women who are treated continuously with bromocriptine throughout pregnancy did not reveal any adverse influences on the course of pregnancy, breastfeeding, or development of their children (163).

Patients should be reassessed 2 months following delivery or cessation of lactation. After delivery, PRL levels may decrease or normalize $(164,165)$. Musolino and Bronstein reported postpartum decreases in PRL levels than in pregestational levels in $60 \%$ of microprolactinoma and $72 \%$ of macroprolactinoma patients (137). Similarly Bergh et al. reported a decrease in serum PRL in 50\% and normalization of PRL in $8 \%$ of patients (166). Whether the improvement of hyperprolactinemia is due to autoinfarction of the adenoma or other mechanisms may be involved is not clarified yet. Pituitary imaging 2 months after the end of lactation is recommended in order to reevaluate the adenoma (162). Reduction in adenoma size after pregnancy in prolactinoma patients is also possible (141).

Patients who wish to breastfeed their infants should not be started on dopamine agonists since they will impair lactation. But patients who have to maintain dopamine agonists to prevent tumor growth should continue their treatment although lactation may be impaired (141). There are no data regarding increased tumor size due to lactation at least to our knowledge. 
Conclusion Prolactinomas are common in females during reproductive age. Treatment of prolactinomas usually restores fertility and results in pregnancies. In microadenomas, due to the low risk of tumor growth, follow-up without treatment according to clinical symptoms can be considered. In macroadenomas, pregnancy should be planned after the control of tumor growth. Close follow-up or dopamine agonist treatment throughout pregnancy may be preferred depending on the patient. To minimize fetal risks, dopamine agonists should be commenced after the first trimester. Pregestational treatment length should be taken into consideration while making a decision about treatment. There is no need for periodical imaging of the prolactinoma during pregnancy, and PRL measurement is of little help. Breastfeeding may be allowed since the data are not enough to be against it. Patients who have to maintain dopamine agonists to prevent tumor growth should continue their treatment although lactation may be impaired.

\section{TSH-secreting adenomas and pregnancy}

There are case reports of TSH-secreting adenomas during pregnancy. Transsphenoidal surgery was performed in a 39-year-old female who developed visual loss at 27 weeks of gestation under bromocriptine and antithyroid treatment (167). Octreotide has also been used in pregnant women with TSH-oma for different periods of time $(119,168)$. As with other pituitary tumors, patients with TSH-omas also need close followup for mass-related symptoms of tumor.

Sometimes thyroid hormone resistance may lead to a diagnostic dilemma due to tumor-like enlargement of the pituitary gland during pregnancy (169).

\section{Gonadotropin-producing pituitary adenomas and pregnancy}

Gonadotropin-producing pituitary adenomas are very rare in women of reproductive age, and there are only a few case reports regarding pregnancy since it causes hypogonadism. It may lead to ovarian hyperstimulation syndrome $(170,171)$. These tumors may be sensitive to bromocriptine via D2R which was demonstrated in the adenoma. Ovarian size can be normalized, and spontaneous conception may be possible following treatment with bromocriptine (171).

\section{Nonfunctioning pituitary adenomas and pregnancy}

Nonfunctioning adenomas are not common during pregnancy since fertility is usually impaired. Tumor debulking is indicated in patients who wish to become pregnant (141). Pregnancy rarely increases the size of clinically nonfunctioning pituitary adenomas. Enlargement of the pituitary adenoma may be due to tumor growth, infarction, or hemorrhage of the tumor during pregnancy. Sometimes apoplexy of pituitary adenoma with visual field loss may be the first sign during pregnancy (172). The risk of visual field defect is increased in patients whose tumor is more than $1.2 \mathrm{~cm}$ in size (143). Increased pituitary gland size due to lactotroph hyperplasia may contribute to the mass effect of pituitary adenomas during pregnancy with a rapid response to bromocriptine (173). Surgery might be considered during the second trimester if needed. Dopamine agonists or conservative management may be preferred in the third trimester.

\section{Craniopharyngiomas and pregnancy}

Craniopharyngiomas usually result in panhypopituitarism due to the tumors themselves or the treatment, so pregnancy is rarely reported with these tumors. Fertility may be achieved with gonadotropin treatment (174). The tumors may increase in size during pregnancy causing visual problems, which usually require surgical intervention (175-177). DI, which is a common symptom of these tumors, can be seen during pregnancy. Hypopituitarism and DI may be the presenting features, but visual deterioration is common with these tumors. Surgery is the treatment of choice if mass effects occur $(178,179)$. Preservation of fertility following excision of craniopharyngioma during pregnancy is also reported (180).

\section{Sheehan's syndrome}

SS is described as postpartum hypopituitarism due to pituitary necrosis caused by severe hypotension or shock secondary to massive bleeding during or just after delivery. The exact pathogenesis and natural history are not understood well (Fig. 5). The clinically significant $\mathrm{SS}$ is not very common due to the developed clinical care today (181). But it is found to be the sixth leading cause of GH deficiency among 1034 GH-deficient patients (182). So it seems that it is not as rare as it is thought to be.

The role of autoimmunity needs to be established in the pathogenesis of SS. Patients with SS do not show increased prevalence of anti-thyroid peroxidase (TPO) positivity compared to controls, but pituitary autoantibody positivity is significantly higher (183-186), although not proven by other studies (187). Recently, antihypothalamus antibodies were found in $40 \%$ and antipituitary antibodies in $35 \%$ of SS patients. So an autoimmune process involving both the hypothalamus and pituitary gland may contribute to delayed pituitary dysfunction in SS patients (188). Although most of the patients with SS reveal an empty or a partially empty sella with a normal sella size $(189,190)$, a relatively small sella may also be a risk factor for the development of SS $(189,191,192)$.

The criteria suggested for the diagnosis of SS are as follows: i) typical obstetric history of severe postpartum 


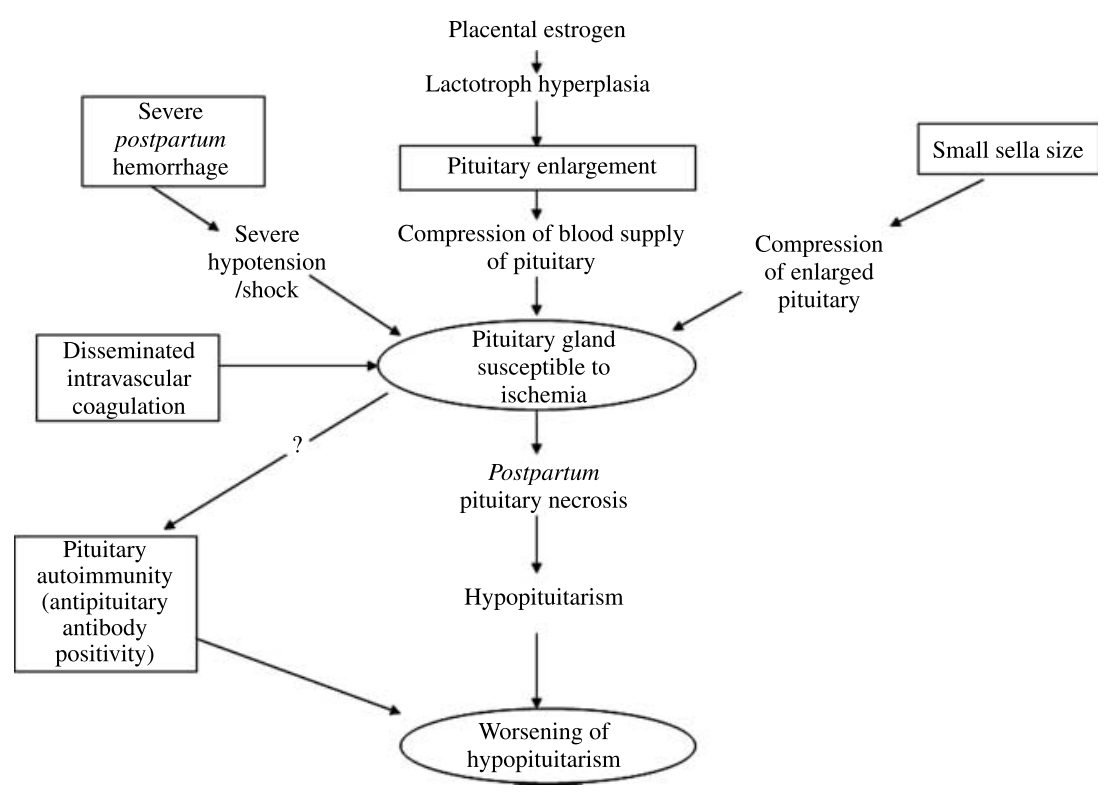

Figure 5 Pathogenesis of Sheehan's syndrome. vaginal bleeding; ii) severe hypotension or shock for which blood transfusion or fluid replacement is necessary; iii) failure of postpartum lactation; iv) failure to resume regular menses after delivery; $v$ ) varying degrees of anterior pituitary failure and partial or panhypopituitarism; vi) empty sella on CT scan or MRI (193).

The symptoms of anterior pituitary dysfunction are usually nonspecific such as weakness, fatigue, and anemia, but severe pituitary insufficiency resulting in coma and death may also be seen $(193,194)$. Postpartum pituitary apoplexy should be kept in mind in patients with hypotension and shock who have a bleeding history during the peripartum period. The mean duration between postpartum hemorrhage and clinical manifestations varies from 1 to 33 or 2 to 40 years without a correlation between severity of hypopituitarism and degree of empty sella $(195,196)$. SS detected in the acute phase is rare (197-199), but most of the SS cases are diagnosed during the early postpartum period in the western countries.

Hypopituitarism due to SS may be of different degrees. Panhypopituitarism is reported in SS in between 55 and $86 \%$ of patients in different studies $(196,200-202)$. GH deficiency is reported in all patients with SS (196, 202-204). It is characterized by more severe GH deficiency than other types of hypopituitarism (205). Although failure of postpartum lactation is a classical symptom of SS, hyperprolactinemia is also reported (206, 207). Adrenocortical insufficiency due to SS results in hypotension, orthostatic hypotension, tiredness, hypopigmentation, and sometimes adrenal crisis under stressful conditions. Secondary hypothyroidism is also very common in SS, and is usually less severe than primary hypothyroidism. Facial edema and periorbital puffiness are usually not seen in SS. Skin is hypopigmented due to ACTH deficiency, and fine wrinkling, which is a remarkable finding of SS, can be seen due to long-term GH and estrogen deficiency. Although atrophy of posterior hypophysis is reported in over $90 \%$ of patients with SS, DI is very rare (208-210). Partial DI is reported to be more frequent than expected (211). The thirst center may be affected by ischemic damage and the osmotic threshold for thirst is increased in patients with SS (212).

Basal hormone levels may be enough in patients with typical histories, but most of the patients need more detailed investigation including dynamic pituitary function tests. Pituitary MRI is the most sensitive method of imaging, but CT may also be helpful. In the early stages, the pituitary gland shows nonhemorrhagic enlargement. Subsequently, the gland atrophies, and an empty sella develops. There is no correlation between the degree of postpartum pituitary necrosis and the severity of clinical expression (213).

Subsequent pregnancies are reported following SS (195, 214-220). Pregnancy might improve hypopituitarism by stimulating the pituitary remnant (221). Recovery of thyrotropic functions after spontaneous pregnancy in SS is reported in a case (222).

Differential diagnosis of SS should be made from spontaneous infarction of pituitary adenoma due to hypotension during or after delivery. Both are characterized by an enlarged pituitary gland in the early stage and varying degrees of hypopituitarism, but decompressive surgery may be necessary for apoplexy of a pituitary adenoma, which is contraindicated in SS. LyH should also be ruled out.

Treatment of SS includes replacement of deficient hormone(s). Glucocorticoid replacement may be lifesaving in severe pituitary insufficiency. During 
maintenance treatment, the minimum dose of glucococorticoid that corrects the clinical symptoms should be given. $\mathrm{L}_{-} \mathrm{T}_{4}$ is the treatment of choice for TSH deficiency. Serum levels of free $\mathrm{T}_{4}$ and clinical findings help to adjust the drug dosage. Hypogonadism should also be treated with estrogen and progesterone in premenopausal women. For women who wish to become pregnant, ovulation induction might be a choice. GH replacement may be useful for improvement of the lipid profile, waist circumference, visceral fat, body composition, carotid artery intima-media thickness, and quality of life (201, 223, 224). GH replacement also has modulatory effects on sebum content of the skin in SS patients (225). GH deficiency has been shown to induce sleep-disturbing effects in SS, but GH replacement was ineffective to reduce these abnormalities (226).

\section{Lymphocytic hypophysitis}

$\mathrm{LyH}$ is an autoimmune disorder characterized by lymphocytic infiltration and destruction of the pituitary gland leading to various degrees of pituitary dysfunction and is associated with other autoimmune disorders. Lymphocytic adenohypophysitis (LAH) is more common in females and is characterized by anterior pituitary dysfunction. Lymphocytic infundibuloneurohypophysitis is characterized clinically by DI and characteristic MRI findings. Lymphocytic panhypophysitis involves both anterior and posterior pituitary (227).

LyH affects females more frequently than males (228). About 55-57\% of females with LAH presented during pregnancy or postpartum with a predilection to the last month of gestation and the first 2 months postpartum (229-232). Earlier presentations in the first or second trimester of pregnancy are also reported (233, 234). LyH does not have adverse effects on the fetus or gestational outcome. Maternal mortality during labor is reported in a case (235). The striking temporal association of pregnancy and $\mathrm{LyH}$ is not clarified yet, but there are possible explanations, which are as follows: i) pregnancy may unmask a latent pituitary insufficiency and lactotroph hyperplasia may contribute to compression signs caused by $\mathrm{LyH}$, both resulting in earlier diagnosis during gestation $(236,237)$. ii) The increased size of pituitary gland, which may lead to the release of pituitary antigens, may be one of the reasons for autoimmune hypophysitis. iii) The pituitary gland may become more accessible to the immune system during pregnancy due to hyperestrogenemia, which changes the pattern of pituitary blood flow and derives more from systemic blood and less from portal circulation (238). iv) Pituitary antibodies are shown to target a $49 \mathrm{kDa}$ cytosolic autoantigen, $\alpha$-enolase, and react with both pituitary and human placental tissue, explaining the relationship between $\mathrm{LyH}$ and pregnancy $(239,240)$. Experimental $\mathrm{LyH}$ in rats has shown that the major antigens are GH, TSH, and LH (241).
Women presenting during pregnancy or the postpartum period usually manifest with symptoms of hypopituitarism and/or symptoms of mass lesion such as headache and visual field defects. Mild hyperprolactinemia and DI may also be found (129). They can also be misdiagnosed as SS when they occur in the postpartum period. The diagnosis of $\mathrm{LyH}$ should be considered, especially in the absence of a history of obstetric hemorrhage, but LyH diagnosed clinically during gestation, which is complicated by postpartum hemorrhage, is also reported (242). In contrast to SS, ACTH is the first hormone to be lost, and hyperprolactinemia is not as uncommon as SS. Hyperprolactinemia affects about one-third of the patients with LyH. Several causes have been suggested for hyperprolactinemia: stalk compression or the inflammatory process itself altering the inhibitory effect of dopamine on PRL or the release of hormones into the bloodstream from destructed tissue or PRL-stimulating antibodies (243-245). Hypoprolactinemia manifested by the inability to lactate after pregnancy may also be seen with LyH $(186,237,246)$.

Diagnosis of LyH is pathological, but imaging studies, especially pituitary MRI, are also very helpful. Diffuse thickening of the pituitary stalk, enhanced contrast enhancement of the gland, and loss of the neurohypophyseal 'bright spot' can be seen on MRI $(247,248)$. LyH can easily be mistaken for a pituitary adenoma and referred for surgery (249). Symmetrical pituitary enlargement, thickened stalk without deviation, uniformly flat sellar floor, appearance of dural tail, which represents the contrast enhancement of dura adjacent to the pituitary, and loss of the 'bright spot' of neurohypophysis are the clues for differentiation from pituitary adenoma (228). The radiological findings of LyH and SS early in the postpartum period may be confusing, and the appearance of an empty sella in the later period can also be seen in $\mathrm{LyH}$, which is typical for SS (250-253) (Fig. 6). Pituitary antibodies may be helpful for suspected cases of LyH presenting with an empty sella. But it has also been reported that autoimmunity per se may not be significantly linked to the occurrence of a primary empty sella (254).

History of previous pregnancies does not increase the risk of developing $\mathrm{LyH}$ in subsequent pregnancies. Pregnancies may occur following a history of $\mathrm{LyH}$ either spontaneously or following ovulation induction (237, 255-258).

Treatment of LyH consists of replacement of deficient pituitary hormones; surgery is preserved for cases with visual impairment or neurological impairment. Bromocriptine has been used in hyperprolactinemic patients with various results with improvement in visual fields (231). Corticosteroids can be used since LyH is an autoimmune disease. Reusch et al. tried a short course of dexamethasone in a pregnant woman because of visual field defects due to a pituitary mass. The patient underwent partial hypophysectomy for decompression since there was a rapid progression of visual field defects 

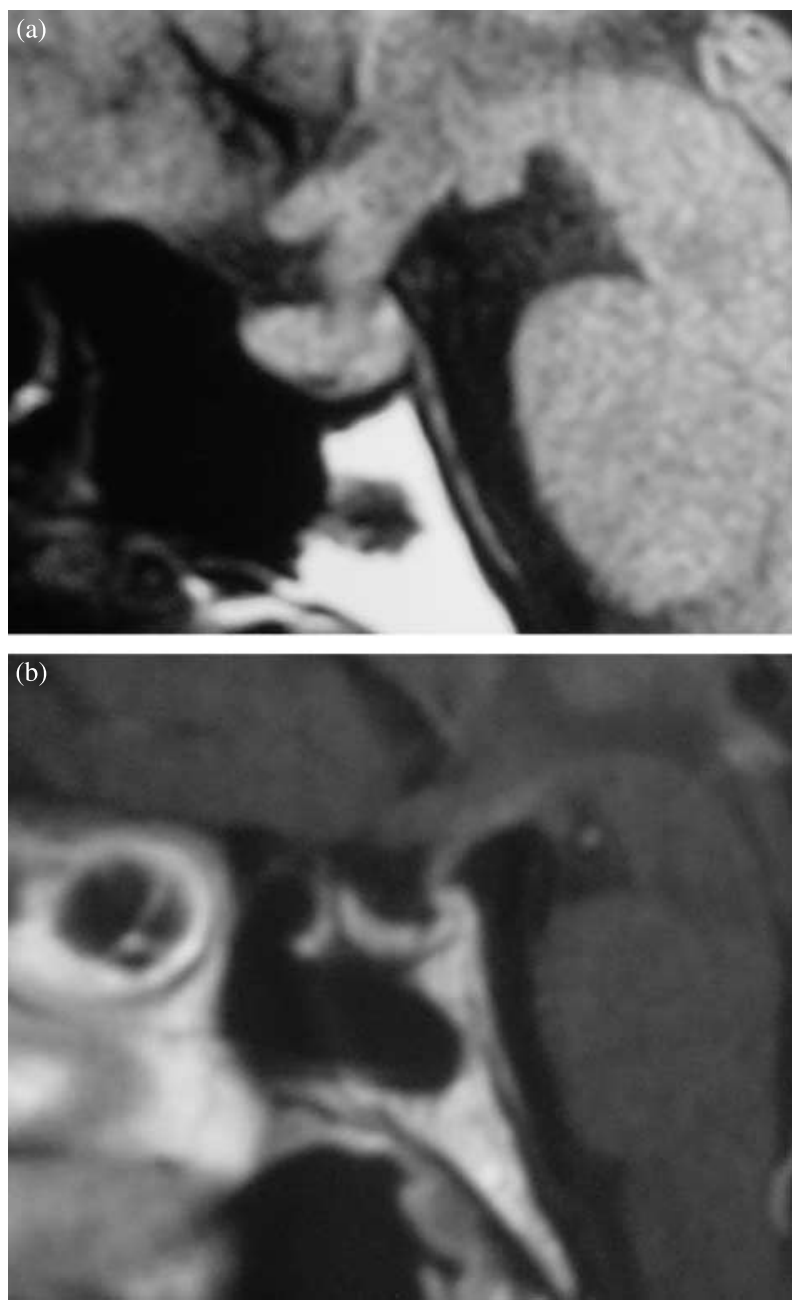

Figure 6 (a) The precontrast sagittal section of pituitary MRI demonstrates thickened pituitary stalk and loss of 'bright spot' of the neurohypophysis in a case of lymphocytic hypophysitis, and (b) the postcontrast sagittal section of pituitary MRI demonstrates empty sella 9 years after the diagnosis of lymphocytic hypophysitis (reproduced from Karaca et al. 2009) (251).

while the patient was on glucocorticoid therapy, and the pathology confirmed the diagnosis of LyH. The authors suggested that the dosage and duration of steroids were ineffective (259). There is no consensus for the dose and length of treatment with corticosteroids, but high doses are usually preferred. The management of LyH during pregnancy should be conservative unless progressive visual deterioration or other mass effects occur. The data are limited regarding surgery or therapeutic doses of steroids for LyH during pregnancy $(233,257)$.

\section{Hypopituitarism and pregnancy}

The introduction of ovulation induction after the 1960s led to normal fecundity in women with hypopituitarism. In the earlier reports, a high rate of spontaneous abortion and maternal mortality was recorded with little information regarding fetal outcome of pregnancies $(218,260,261)$. More detailed studies were carried out later. Twin pregnancies had poorer outcomes, which is attributed to incomplete preparation of the uterus before pregnancy leading to poor placental function. Twin pregnancies should be avoided in this particular group of patients despite increased cost, and more attention should be paid to the preparation of the uterus with estrogen and growth hormone for gestation (262). In hypopituitary patients, the pregnancy rate is reported as $47 \%$ and birth rate as $42 \%$ (263). The ovulation and conception rates are higher, and spontaneous miscarriage rates are lower in isolated hypogonadotropic hypogonadism (HH) cases (264). Uterine size is reported to be similar in $\mathrm{HH}$ and hypopituitarism (265). Therefore, uterine size alone cannot explain the poorer outcome of patients with hypopituitarism. Probably, associated pituitary hormone deficiencies might play a role.

There are much more data regarding isolated $\mathrm{GH}$ deficiency than those regarding isolated ACTH and TSH deficiencies. An intact GH-IGF1 axis is not always essential for normal fertility, but it has been established that GH deficiency leads to difficulties in conception and subfertility (266). The use of GH in GH-deficient patients increases ovarian sensitivity to endogenous gonadotropins (267), but the use of GH has not proven to be useful in patients with intact pituitary function (268). GH treatment has been used successfully in a GH-deficient patient during pregnancy (269). Although GH deficiency is reported to result in uneventful pregnancies $(266,270-272)$, its use during pregnancy is not approved. GH therapy during pregnancy in GH-deficient women might be important for placental function and fetal growth, especially before and during conception and in the early weeks of gestation. It becomes less important in the later stages of pregnancy because there is a progressive rise of $\mathrm{GH}$ after the 20th week of pregnancy with decrement in pituitary GH in maternal serum (47). GH was suggested to improve gonadotropin hormonal action in follicular development, which could be necessary in eugonadal patients with GH deficiency (273). Gestational GH therapy in the first two trimesters of pregnancy was reported to be safe for the mother and the fetus without important adverse events and obstetric complications (274). So fertilization problems and early gestational complications such as abortions and miscarriages can be prevented by use of $\mathrm{GH}$ in GH-deficient women either in isolated deficiencies or accompanied by other hormone deficiencies.

Adrenal insufficiency is associated with increased morbidity and mortality during pregnancy if undiagnosed or left untreated (275). However, it may be difficult to recognize adrenal insufficiency during pregnancy. Signs and symptoms such as emesis, fatigue, and mild hyponatremia may be ignored since they can also be seen in a normal pregnancy. Pregnancy is a state of physiological hypercortisolism where CBG and 
cortisol levels increase. An insulin tolerance test and metyrapone tests are contraindicated during pregnancy, and the $\mathrm{CRH}$ test is useless due to its placental production (86). Standard ACTH stimulation test should be preferred during pregnancy, although cutoff values are not determined to diagnose adrenal insufficiency in pregnant women. Suri et al. demonstrated nearly twofold elevations in total serum cortisol and salivary cortisol and eightfold elevations in serum aldosterone in the late gestation than in the nonpregnant stage. Increased adrenal response to ACTH despite increasing basal cortisol and aldosterone was observed as the pregnancy progressed. They suggested salivary cortisol to be more consistent and generalizable than total serum cortisol (276). Hydrocortisone or prednisolone may be preferred to dexamethasone for the treatment of maternal adrenal insufficiency (277, 278). Patients on glucocorticoid replacement may need to increase their hydrocortisone dose by $50 \%$ during the last trimester of pregnancy. By the start of the labor, the hydrocortisone dose should be increased to stress doses till 48 h postpartum $(279,280)$. Glucocorticoids may pass to breast milk, but the amounts are insufficient to affect neonatal adrenal functions (281).

Central hypothyroidism is characterized by low levels of serum free $\mathrm{T}_{4}$ and TSH, but in most of the young patients, TSH may be normal, which is explained by reduced bioactivity of TSH, perhaps due to increased glycosylation of the molecule. Replacement with $\mathrm{L}_{-} \mathrm{T}_{4}$ by adjusting the dose to keep free $\mathrm{T}_{4}$ in the upper half of the normal range for the age is recommended (282). There are no reliable trimester-specific ranges for TSH, but levels of $0.2-2.5 \mathrm{mU} / \mathrm{l}$ are considered to be the normal range for pregnant women. Women with known hypothyroidism before pregnancy should increase the $\mathrm{L}_{-} \mathrm{T}_{4}$ dose by $25-50 \%$ as early as possible, ideally by the fourth week of gestation (69). Approximately one-third of the maternal thyroid hormone crosses to the fetus, and it plays an important role in fetal neurodevelopment in the first half of pregnancy prior to fetal pituitary-thyroid axis development (283).

Mild DI may worsen in pregnant patients, and asymptomatic women may become symptomatic during pregnancy. Patients treated with pitressin tannate oil and lysine AVP spray may also experience such worsening, but not with desmopressin since it is not degraded by vasopressinase (284-286). Desmopressin seems safe during pregnancy, except for a small risk of increased uterine contractility due to its oxytocin-like structure and activity. However, this effect is more prominent during i.v. use rather than during nasal use (287). Since desmopressin is transferred to breast milk in little amounts and gastrointestinal absorption is poor, breastfeeding does not affect water metabolism of the infant (284-286).

Gestational DI is a rare endocrinopathy due to excessive vasopressinase activity. It is categorized into three groups: AVP resistant and dDAVP sensitive, AVP and dDAVP resistant (nephrogenic), and AVP and dDAVP sensitive (central). Besides placental vasopressinase activity, transient liver dysfunction may decrease the degradation of vasopressinase in the liver. This may explain the association of acute fatty liver of pregnancy and HELLP syndrome (288-291). Therefore, women developing DI late in gestation should be screened for liver function abnormalities.

Primary empty sella is reported rarely during pregnancy since it is associated with infertility due to hypogonadism or pituitary hormone deficiencies. There are case reports of women treated for $\mathrm{HH}$ or $\mathrm{GH}$ deficiency in eugonadism resulting in successful pregnancies $(273,292,293)$.

Conclusion Hypopituitarism during pregnancy should be managed carefully. Patients treated for hypoadrenalism and hypothyroidism may need to increase their replacement doses during gestation. The growth hormone is not replaced routinely during pregnancy, but for planned pregnancies, GH may be used until confirmation of pregnancy, which helps preparation of the uterus for conception and results in better fertilization results. Asymptomatic DI may become symptomatic during pregnancy, and dDAVP dose may need to be increased.

\section{Conclusion}

The anatomy and physiology of the pituitary gland are almost completely altered during pregnancy. For better understanding the mechanisms of both the anatomical and the physiological changes of the pituitary and pituitary diseases during pregnancy, in vivo studies with larger numbers are required. Multicenter studies and databases recording pregnant patients with pituitary disorders might help to make consensus statements.

\section{Declaration of interest}

The authors declare that there is no conflict of interest that could be perceived as prejudicing the impartiality of the research reported.

\section{Funding}

We did not receive any specific grant from any funding agency in the public, commercial, or not-for-profit sector.

\section{Acknowledgements}

The authors express their profound gratitude to their medical illustrator, Tuna Ferit Hidayetoglu, for his original artwork.

\section{References}

1 Melmed S \& Kleinberg D. Anterior pituitary. In Williams Textbook of Endocrinology, edn 10, ch 8, pp 177-279. Eds PR Larsen, HM Kronenberg, S Melmed \& KS Polonsky. Philadelphia, PA: Saunders, 2003. 
2 Amar AP \& Weiss MH. Pituitary anatomy and physiology. Neurosurgery Clinics of North America 2003 14 11-23.

3 Elster AD. Modern imaging of the pituitary. Radiology 1993187 $1-14$.

4 Comte L. Contribution a l'etude de l'hypophse humaine. Doctoral Thesis 1898. Switzerland: Lausanne.

5 Goluboff LG \& Ezrin C. Effect of pregnancy on the somatotroph and the prolactin cell of the human adenohypophysis. Journal of Clinical Endocrinology and Metabolism 196929 1533-1538.

6 Scheithauer BW, Sano T, Kovacs KT, Young WF Jr, Ryan N \& Randall RV. The pituitary gland in pregnancy: a clinicopathologic and immunohistochemical study of 69 cases. Mayo Clinic Proceedings 199065 461-474.

7 Gonzalez JG, Elizondo G, Saldivar D, Nanez H, Todd LE \& Villarreal JZ. Pituitary gland growth during normal pregnancy: an in vivo study using magnetic resonance imaging. American Journal of Medicine $1988 \mathbf{8 5} 217-220$.

8 Dinc H, Esen F, Demirci A, Sari A \& Resit GH. Pituitary dimensions and volume measurements in pregnancy and post partum. MR assessment. Acta Radiologica $19983964-69$.

9 Elster AD, Sanders TG, Vines FS \& Chen MY. Size and shape of the pituitary gland during pregnancy and post partum: measurement with MR imaging. Radiology $1991181531-535$.

10 Wolpert SM, Molitch ME, Goldman JA \& Wood JB. Size, shape, and appearance of the normal female pituitary gland. American Journal of Roentgenology 1984143 377-381.

11 Chen HW, Su DH, Chen HW, Yang CH \& Chang CC. Abnormal enlargement of pituitary gland during pregnancy remitted spontaneously after delivery. Chang Gung Medical Journal 2007 30 81-86.

12 Heald AH, Hughes D, King A \& Buckler H. Pregnancy related pituitary enlargement mimicking macroadenoma. British Journal of Neurosurgery 200418 524-526.

13 Inoue T, Hotta A, Awai M \& Tanihara H. Loss of vision due to a physiologic pituitary enlargement during normal pregnancy. Graefe's Archive for Clinical and Experimental Ophthalmology 2007 245 1049-1051.

14 Kanal E, Barkovich AJ, Bell C, Borgstede JP, Bradley WG Jr, Froelich JW, Gilk T, Gimbel JR, Gosbee J, Kuhni-Kaminski E, Lester JW Jr, Nyenhuis J, Parag Y, Schaefer DJ, Sebek-Scoumis EA, Weinreb J, Zaremba LA, Wilcox P, Lucey L \& Sass N. ACR guidance document for safe MR practices. American Journal of Roentgenology $2007 \mathbf{1 8 8} 1447-1474$.

15 Lin SP \& Brown JJ. MR contrast agents: physical and pharmacologic basics. Journal of Magnetic Resonance Imaging 200725 884-899.

16 Barkhof F, Heijboer RJ \& Algra PR. Inadvertent i.v. administration of gadopentetate dimeglumine during early pregnancy. American Journal of Roentgenology 19921581171.

17 Birchard KR, Brown MA, Hyslop WB, Firat Z \& Semelka RC. MRI of acute abdominal and pelvic pain in pregnant patients. American Journal of Roentgenology 2005184 452-458.

18 Marcos HB, Semelka RC \& Worawattanakul S. Normal placenta: gadolinium-enhanced dynamic MR imaging. Radiology 1997 205 493-496.

19 Shoenut JP, Semelka RC, Silverman R, Yaffe CS \& Micflikier AB. MRI in the diagnosis of Crohn's disease in two pregnant women. Journal of Clinical Gastroenterology 199317 244-247.

20 Carr BR, Parker CR Jr, Madden JD, MacDonald PC \& Porter JC. Maternal plasma adrenocorticotropin and cortisol relationships throughout human pregnancy. American Journal of Obstetrics and Gynecology $1981139416-422$.

21 Nolten WE, Lindheimer MD, Rueckert PA, Oparil S \& Ehrlich EN. Diurnal patterns and regulation of cortisol secretion in pregnancy. Journal of Clinical Endocrinology and Metabolism $198051466-472$

22 Scott EM, McGarrigle HH \& Lachelin GC. The increase in plasma and saliva cortisol levels in pregnancy is not due to the increase in corticosteroid-binding globulin levels. Journal of Clinical Endocrinology and Metabolism 199071 639-644.
23 Demey-Ponsart E, Foidart JM, Sulon J \& Sodoyez JC. Serum CBG, free and total cortisol and circadian patterns of adrenal function in normal pregnancy. Journal of Steroid Biochemistry 198216 $165-169$.

24 Allolio B, Hoffmann J, Linton EA, Winkelmann W, Kusche M \& Schulte HM. Diurnal salivary cortisol patterns during pregnancy and after delivery relationship to plasma corticotrophin-releasing-hormone. Clinical Endocrinology 199033 279-289.

25 Cousins L, Rigg L, Hollingsworth D, Meis P, Halberg F, Brink G \& Yen SS. Qualitative and quantitative assessment of the circadian rhythm of cortisol in pregnancy. American Journal of Obstetrics and Gynecology $1983 \mathbf{1 4 5} 411-416$.

26 Magiakou MA, Mastorakos G, Rabin D, Margioris AN, Dubbert B, Calogero AE, Tsigos C, Munson PJ \& Chrousos GP. The maternal hypothalamic-pituitary-adrenal axis in the third trimester of human pregnancy. Clinical Endocrinology $1996 \mathbf{4 4} 419-428$.

27 Mukherjee K \& Swyer GI. Plasma cortisol and adrenocorticotrophic hormone in normal men and non-pregnant women, normal pregnant women and women with pre-eclampsia. Journal of Obstetrics and Gynaecology of the British Commonwealth $197279504-512$.

28 Lindsay JR \& Nieman LK. The hypothalamic-pituitary-adrenal axis in pregnancy: challenges in disease detection and treatment. Endocrine Reviews 200526 775-799.

29 Seckl JR, Cleasby M \& Nyirenda MJ. Glucocorticoids, 11ßhydroxysteroid dehydrogenase, and fetal programming. Kidney International $2000 \mathbf{5 7} 1412-1417$.

30 Murphy BE. Conversion of cortisol to cortisone by the human uterus and its reversal in pregnancy. Journal of Clinical Endocrinology and Metabolism 1977 44 1214-1217.

31 Atkinson HC \& Waddell BJ. The hypothalamic-pituitary-adrenal axis in rat pregnancy and lactation: circadian variation and interrelationship of plasma adrenocorticotropin and corticosterone. Endocrinology $1995136512-520$.

32 Demura R, Odagiri E, Yoshimura M, Jibiki K, Adachi T, Shirota M, Demura H, Shizume K \& Oouchi H. Placental secretion of prolactin, ACTH and immunoreactive beta-endorphin during pregnancy. Acta Endocrinologica 1982100 114-119.

33 Petraglia F, Sawchenko PE, Rivier J \& Vale W. Evidence for local stimulation of ACTH secretion by corticotropin-releasing factor in human placenta. Nature 1987328 717-719.

34 Fadalti M, Pezzani I, Cobellis L, Springolo F, Petrovec MM, Ambrosini G, Reis FM \& Petraglia F. Placental corticotropinreleasing factor. An update. Annals of the New York Academy of Sciences 2000900 89-94.

35 Blumenfeld Z \& Jaffe RB. Hypophysiotropic and neuromodulatory regulation of adrenocorticotropin in the human fetal pituitary gland. Journal of Clinical Investigation $1986 \mathbf{7 8} 288-294$.

36 Robinson BG, Emanuel RL, Frim DM \& Majzoub JA. Glucocorticoid stimulates expression of corticotropin-releasing hormone gene in human placenta. PNAS $1988 \mathbf{8 5} 5244-5248$.

37 Sasaki A, Shinkawa O \& Yoshinaga K. Placental corticotropinreleasing hormone may be a stimulator of maternal pituitary adrenocorticotropic hormone secretion in humans. Journal of Clinical Investigation 198984 1997-2001.

38 Hobel CJ, Arora CP \& Korst LM. Corticotrophin-releasing hormone and CRH-binding protein. Differences between patients at risk for preterm birth and hypertension. Annals of the New York Academy of Sciences $1999 \mathbf{8 9 7} 54-65$.

39 Sehringer B, Zahradnik HP, Simon M, Ziegler R, Noethling C \& Schaefer WR. mRNA expression profiles for corticotrophinreleasing hormone, urocortin, CRH-binding protein and $\mathrm{CRH}$ receptors in human term gestational tissues determined by realtime quantitative RT-PCR. Journal of Molecular Endocrinology 200432 339-348.

40 Kalantaridou SN, Makrigiannakis A, Mastorakos G \& Chrousos GP. Roles of reproductive corticotropin-releasing hormone. Annals of the New York Academy of Sciences $2003 \mathbf{9 9 7}$ 129-135. 
41 Verhaeghe J. Does the physiological acromegaly of pregnancy benefit the fetus? Gynecologic and Obstetric Investigation $2008 \mathbf{6 6}$ 217-226.

42 El Kasti MM, Christian HC, Huerta-Ocampo I, Stolbrink M, Gill S, Houston PA, Davies JS, Chilcott J, Hill N, Matthews DR, Carter DA \& Wells T. The pregnancy-induced increase in baseline circulating growth hormone in rats is not induced by ghrelin. Journal of Neuroendocrinology 200820 309-322.

43 Chellakooty M, Vangsgaard K, Larsen T, Scheike T, FalckLarsen J, Legarth J, Andersson AM, Main KM, Skakkebaek NE \& Juul A. A longitudinal study of intrauterine growth and the placental growth hormone (GH)-insulin-like growth factor 1 axis in maternal circulation: association between placental GH and fetal growth. Journal of Clinical Endocrinology and Metabolism 200489 384-391.

44 Fuglsang J, Sandager P, Moller N, Fisker S, Frystyk J \& Ovesen P. Peripartum maternal and foetal ghrelin, growth hormones, IGFs and insulin interrelations. Clinical Endocrinology $2006 \mathbf{6 4}$ 502-509.

45 Igout A, Frankenne F, L'Hermite-Baleriaux M, Martin A \& Hennen G. Somatogenic and lactogenic activity of the recombinant $22 \mathrm{kDa}$ isoform of human placental growth hormone. Growth Regulation 19955 60-65.

46 Eriksson L, Frankenne F, Eden S, Hennen G \& Von Schoultz B. Growth hormone 24-h serum profiles during pregnancy - lack of pulsatility for the secretion of the placental variant. British Journal of Obstetrics and Gynaecology 198996 949-953.

47 Frankenne F, Closset J, Gomez F, Scippo ML, Smal J \& Hennen G. The physiology of growth hormones (GHs) in pregnant women and partial characterization of the placental GH variant. Journal of Clinical Endocrinology and Metabolism $1988 \mathbf{6 6}$ 1171-1180.

48 de Zegher F, Vanderschueren-Lodeweyckx M, Spitz B, Faijerson Y, Blomberg F, Beckers A, Hennen G \& Frankenne F. Perinatal growth hormone (GH) physiology: effect of GH-releasing factor on maternal and fetal secretion of pituitary and placental $\mathrm{GH}$. Journal of Clinical Endocrinology and Metabolism $1990 \mathbf{7 1}$ 520-522.

49 Samaan NA, Goplerud CP \& Bradbury JT. Effect of arginine infusion on plasma levels of growth hormone, insulin, and glucose during pregnancy and the puerperium. American Journal of Obstetrics and Gynecology $1970 \mathbf{1 0 7} 1002-1007$.

50 Yen SS, Vela P \& Tsai CC. Impairment of growth hormone secretion in response to hypoglycemia during early and late pregnancy. Journal of Clinical Endocrinology and Metabolism 1970 $3129-32$.

51 Rigg LA, Lein A \& Yen SS. Pattern of increase in circulating prolactin levels during human gestation. American Journal of Obstetrics and Gynecology 1977129 454-456.

52 Bohnet HG, Naber NG, del Pozo E \& Schneider HP. Effects of synthetic gestagens on serum prolactin and growth hormone secretion in amenorrheic patients. Archives of Gynecology 1978 226 233-240.

53 Riddick DH, Luciano AA, Kusmik WF \& Maslar IA. Evidence for a nonpituitary source of amniotic fluid prolactin. Fertility and Sterility 197931 35-39.

54 Foyouzi N, Frisbaek Y \& Norwitz ER. Pituitary gland and pregnancy. Obstetrics and Gynecology Clinics of North America $200431873-892$ (xi).

55 Kwa HG, Cleton F, Bulbrook RD, Wang DY \& Hayward JL. Plasma prolactin levels and breast cancer: relation to parity, weight and height, and age at first birth. International Journal of Cancer 1981 28 31-34.

56 Yu MC, Gerkins VR, Henderson BE, Brown JB \& Pike MC. Elevated levels of prolactin in nulliparous women. British Journal of Cancer $198143826-831$.

57 Farkouh NH, Packer MG \& Frantz AG. Large molecular size prolactin with reduced receptor activity in human serum: high proportion in basal state and reduction after thyrotropinreleasing hormone. Journal of Clinical Endocrinology and Metabolism $1979 \mathbf{4 8} 1026-1032$.
58 Pansini F, Bergamini CM, Malfaccini M, Cocilovo G, Linciano M, Jacobs M \& Bagni B. Multiple molecular forms of prolactin during pregnancy in women. Journal of Endocrinology 1985106 81-85.

59 Suh HK \& Frantz AG. Size heterogeneity of human prolactin in plasma and pituitary extracts. Journal of Clinical Endocrinology and Metabolism 197439 928-935.

60 Hattori N. The frequency of macroprolactinemia in pregnant women and the heterogeneity of its etiologies. Journal of Clinical Endocrinology and Metabolism 199681 586-590.

61 Pascoe-Lira D, Duran-Reyes G, Contreras-Hernandez I, ManuelApolinar L, Blanco-Favela F \& Leanos-Miranda A. Frequency of macroprolactinemia due to autoantibodies against prolactin in pregnant women. Journal of Clinical Endocrinology and Metabolism $200186924-929$.

62 Leanos-Miranda A, Pascoe-Lira D, Chavez-Rueda KA \& Blanco-Favela F. Persistence of macroprolactinemia due to antiprolactin autoantibody before, during, and after pregnancy in a woman with systemic lupus erythematosus. Journal of Clinical Endocrinology and Metabolism 2001 86 2619-2624.

63 Glinoer D, de Nayer P, Bourdoux P, Lemone M, Robyn C, van Steirteghem A, Kinthaert J \& Lejeune B. Regulation of maternal thyroid during pregnancy. Journal of Clinical Endocrinology and Metabolism 199071 276-287.

64 Burrow GN, Fisher DA \& Larsen PR. Maternal and fetal thyroid function. New England Journal of Medicine 1994331 1072-1078.

65 Glinoer D. The regulation of thyroid function in pregnancy: pathways of endocrine adaptation from physiology to pathology. Endocrine Reviews $1997 \mathbf{1 8}$ 404-433.

66 Roti E, Gardini E, Minelli R, Bianconi L \& Flisi M. Thyroid function evaluation by different commercially available free thyroid hormone measurement kits in term pregnant women and their newborns. Journal of Endocrinological Investigation 199114 1-9.

67 Guillaume J, Schussler GC \& Goldman J. Components of the total serum thyroid hormone concentrations during pregnancy: high free thyroxine and blunted thyrotropin (TSH) response to TSHreleasing hormone in the first trimester. Journal of Clinical Endocrinology and Metabolism $1985 \mathbf{6 0} 678-684$.

68 Weeke J, Dybkjaer L, Granlie K, Eskjaer JS, Kjaerulff E, Laurberg P \& Magnusson B. A longitudinal study of serum TSH, and total and free iodothyronines during normal pregnancy. Acta Endocrinologica $1982 \mathbf{1 0 1} 531-537$.

69 Mandel SJ, Larsen PR, Seely EW \& Brent GA. Increased need for thyroxine during pregnancy in women with primary hypothyroidism. New England Journal of Medicine 1990323 91-96.

70 Reyes FI, Winter JS \& Faiman C. Pituitary gonadotropin function during human pregnancy: serum FSH and LH levels before and after LHRH administration. Journal of Clinical Endocrinology and Metabolism $1976 \mathbf{4 2}$ 590-592.

71 Davison JM, Vallotton MB \& Lindheimer MD. Plasma osmolality and urinary concentration and dilution during and after pregnancy: evidence that lateral recumbency inhibits maximal urinary concentrating ability. British Journal of Obstetrics and Gynaecology $1981 \mathbf{8 8} 472-479$.

72 Shehata HA \& Okosun H. Neurological disorders in pregnancy. Current Opinion in Obstetrics and Gynecology 200416 117-122.

73 Hime MC \& Richardson JA. Diabetes insipidus and pregnancy. Case report, incidence and review of literature. Obstetrical and Gynecological Survey 197833 375-379.

74 Lado-Abeal J, Rodriguez-Arnao J, Newell-Price JD, Perry LA, Grossman AB, Besser GM \& Trainer PJ. Menstrual abnormalities in women with Cushing's disease are correlated with hypercortisolemia rather than raised circulating androgen levels. Journal of Clinical Endocrinology and Metabolism $1998 \mathbf{8 3} 3083-3088$.

75 Yamaji T, Ishibashi M, Teramoto A \& Fukushima T. Hyperprolactinemia in Cushing's disease and Nelson's syndrome. Journal of Clinical Endocrinology and Metabolism 198458 790-795.

76 Guilhaume B, Sanson ML, Billaud L, Bertagna X, Laudat MH \& Luton JP. Cushing's syndrome and pregnancy: aetiologies and prognosis in twenty-two patients. European Journal of Medicine $1992183-89$. 
77 Lubin V, Gautier JF, Antoine JM, Beressi JP \& Vexiau P. Cushing's syndrome during pregnancy. Presse Médicale $2002 \mathbf{3 1}$ 1706-1713.

78 Miyoshi T, Otsuka F, Suzuki J, Inagaki K, Takeda M, Kano Y, Yamashita T, Ogura T, Date I, Tanaka Y, Hashimoto K \& Makino H. Periodic secretion of adrenocorticotropin in a patient with Cushing's disease manifested during pregnancy. Endocrine Journal 200552 287-292.

79 Chico A, Manzanares JM, Halperin I, Martinez de Osaba MJ, Adelantado J \& Webb SM. Cushing's disease and pregnancy: report of six cases. European Journal of Obstetrics, Gynecology, and Reproductive Biology $1996 \mathbf{6 4} 143-146$.

80 Sheeler LR. Cushing's syndrome and pregnancy. Endocrinology and Metabolism Clinics of North America 199423 619-627.

81 Prebtani AP, Donat D \& Ezzat S. Worrisome striae in pregnancy. Lancet 20003551692.

82 Tajika T, Shinozaki T, Watanabe H, Yangawa T \& Takagishi K. Case report of a Cushing's syndrome patient with multiple pathologic fractures during pregnancy. Journal of Orthopaedic Science $20027498-500$.

83 Odagiri E, Ishiwatari N, Abe Y, Jibiki K, Adachi T, Demura R, Demura H \& Shizume K. Hypercortisolism and the resistance to dexamethasone suppression during gestation. Endocrinologia Japonica 198835 685-690.

84 Nieman LK, Biller BM, Findling JW, Newell-Price J, Savage MO, Stewart PM \& Montori VM. The diagnosis of Cushing's syndrome: an Endocrine Society Clinical Practice Guideline. Journal of Clinical Endocrinology and Metabolism 200893 1526-1540.

85 Polli N, Pecori GF \& Cavagnini F. Cushing's disease and pregnancy. Pituitary 20047 237-241.

86 Schulte HM, Weisner D \& Allolio B. The corticotrophin releasing hormone test in late pregnancy: lack of adrenocorticotrophin and cortisol response. Clinical Endocrinology 199033 99-106.

87 Suda T, Iwashita M, Ushiyama T, Tozawa F, Sumitomo T, Nakagami Y, Demura H \& Shizume K. Responses to corticotropinreleasing hormone and its bound and free forms in pregnant and nonpregnant women. Journal of Clinical Endocrinology and Metabolism 198969 38-42.

88 Mellor A, Harvey RD, Pobereskin LH \& Sneyd JR. Cushing's disease treated by trans-sphenoidal selective adenomectomy in mid-pregnancy. British Journal of Anaesthesia $1998 \mathbf{8 0} 850-852$.

89 Coyne TJ, Atkinson RL \& Prins JB. Adrenocorticotropic hormonesecreting pituitary tumor associated with pregnancy: case report. Neurosurgery 199231 953-955.

90 Pinette MG, Pan YQ, Oppenheim D, Pinette SG \& Blackstone J. Bilateral inferior petrosal sinus corticotropin sampling with corticotropin-releasing hormone stimulation in a pregnant patient with Cushing's syndrome. American Journal of Obstetrics and Gynecology 1994171 563-564.

91 Buescher MA, McClamrock HD \& Adashi EY. Cushing syndrome in pregnancy. Obstetrics and Gynecology $199279130-137$.

92 Casson IF, Davis JC, Jeffreys RV, Silas JH, Williams J \& Belchetz PE. Successful management of Cushing's disease during pregnancy by transsphenoidal adenectomy. Clinical Endocrinology 198727 423-428.

93 Bevan JS, Othman S, Lazarus JH, Parkes AB \& Hall R. Reversible adrenocorticotropin deficiency due to probable autoimmune hypophysitis in a woman with postpartum thyroiditis. Journal of Clinical Endocrinology and Metabolism 1992 74 548-552.

94 Verdugo C, Donoso J, Meza H, Domke G, Esterio H, Martinez A \& Cruz G. Cushing's syndrome and pregnancy with spontaneous remission after delivery. Revista Médica de Chile 1982110 564-569.

95 Chiodini I, Losa M, Pavone G, Trischittal V \& Scillitani A. Pregnancy in Cushing's disease shortly after treatment by gamma-knife radiosurgery. Journal of Endocrinological Investigation 200427 954-956.

96 Amado JA, Pesquera C, Gonzalez EM, Otero M, Freijanes J \& Alvarez A. Successful treatment with ketoconazole of Cushing's syndrome in pregnancy. Postgraduate Medical Journal 199066 221-223.
97 Berwaerts J, Verhelst J, Mahler C \& Abs R. Cushing's syndrome in pregnancy treated by ketoconazole: case report and review of the literature. Gynecological Endocrinology 199913 175-182.

98 Sonino N. The use of ketoconazole as an inhibitor of steroid production. New England Journal of Medicine 1987317 812-818.

99 Cabezon C, Bruno OD, Cohen M, Garcia S \& Gutman RA. Twin pregnancy in a patient with Cushing's disease. Fertility and Sterility 199972 371-372.

100 Close CF, Mann MC, Watts JF \& Taylor KG. ACTH-independent Cushing's syndrome in pregnancy with spontaneous resolution after delivery: control of the hypercortisolism with metyrapone. Clinical Endocrinology 199339 375-379.

101 Connell JM, Cordiner J, Davies DL, Fraser R, Frier BM \& McPherson SG. Pregnancy complicated by Cushing's syndrome: potential hazard of metyrapone therapy. Case report. British Journal of Obstetrics and Gynaecology 198592 1192-1195.

102 Gormley MJ, Hadden DR, Kennedy TL, Montgomery DA, Murnaghan GA \& Sheridan B. Cushing's syndrome in pregnancy - treatment with metyrapone. Clinical Endocrinology 198216 283-293.

103 Hana V, Dokoupilova M, Marek J \& Plavka R. Recurrent ACTHindependent Cushing's syndrome in multiple pregnancies and its treatment with metyrapone. Clinical Endocrinology $20015 \mathbf{5 4}$ 277-281.

104 Wallace C, Toth EL, Lewanczuk RZ \& Siminoski K. Pregnancyinduced Cushing's syndrome in multiple pregnancies. Journal of Clinical Endocrinology and Metabolism 199681 15-21.

105 Leiba S, Weinstein R, Shindel B, Lapidot M, Stern E, Levavi H, Rusecki Y \& Abramovici A. The protracted effect of $o, p^{\prime}$-DDD in Cushing's disease and its impact on adrenal morphogenesis of young human embryo. Annales d'Endocrinologie 198950 49-53.

106 Biller BM, Grossman AB, Stewart PM, Melmed S, Bertagna X, Bertherat J, Buchfelder M, Colao A, Hermus AR, Hofland LJ, Klibanski A, Lacroix A, Lindsay JR, Newell-Price J, Nieman LK, Petersenn S, Sonino N, Stalla GK, Swearingen B, Vance ML, Wass JA \& Boscaro M. Treatment of adrenocorticotropindependent Cushing's syndrome: a consensus statement. Journal of Clinical Endocrinology and Metabolism $2008 \mathbf{9 3}$ 2454-2462.

107 Sauder SE, Frager M, Case GD, Kelch RP \& Marshall JC. Abnormal patterns of pulsatile luteinizing hormone secretion in women with hyperprolactinemia and amenorrhea: responses to bromocriptine. Journal of Clinical Endocrinology and Metabolism 198459 941-948.

108 Herman-Bonert V, Seliverstov M \& Melmed S. Pregnancy in acromegaly: successful therapeutic outcome. Journal of Clinical Endocrinology and Metabolism 199883 727-731.

109 Unal A, Sahin Y \& Kelestimur F. Acromegaly with polycystic ovaries, hyperandrogenism, hirsutism, insulin resistance and acanthosis nigricans: a case report. Endocrine Journal 199340 207-211.

110 Beckers A, Stevenaert A, Foidart JM, Hennen G \& Frankenne F. Placental and pituitary growth hormone secretion during pregnancy in acromegalic women. Journal of Clinical Endocrinology and Metabolism 199071 725-731.

111 Hisano M, Sakata M, Watanabe N, Kitagawa M, Murashima A \& Yamaguchi K. An acromegalic woman first diagnosed in pregnancy. Archives of Gynecology and Obstetrics $2006 \mathbf{2 7 4}$ 171-173.

112 Mozas J, Ocon E, de La Torre ML, Suarez AM, Miranda JA \& Herruzo AJ. Successful pregnancy in a woman with acromegaly treated with somatostatin analog (octreotide) prior to surgical resection. International Journal of Gynaecology and Obstetrics 1999 $6571-73$.

113 Chang-DeMoranville BM \& Jackson IM. Diagnosis and endocrine testing in acromegaly. Endocrinology and Metabolism Clinics of North America 199221 649-668.

114 Barkan AL, Stred SE, Reno K, Markovs M, Hopwood NJ, Kelch RP \& Beitins IZ. Increased growth hormone pulse frequency in acromegaly. Journal of Clinical Endocrinology and Metabolism 1989 $691225-1233$. 
115 Newman CB. Medical therapy for acromegaly. Endocrinology and Metabolism Clinics of North America 199928 171-190.

116 Jaspers C, Haase R, Pfingsten H, Benker G \& Reinwein D. Long-term treatment of acromegalic patients with repeatable parenteral depot-bromocriptine. Clinical Investigator 199371 $547-551$.

117 Miyakawa I, Taniyama K, Koike H, Mori N, Nagamine M, Kuribayashi T \& Araki S. Successful pregnancy in an acromegalic patient during 2-Br-alpha-ergocryptine (CB-154) therapy. Acta Endocrinologica $1982101333-338$.

118 Yap AS, Clouston WM, Mortimer RH \& Drake RF. Acromegaly first diagnosed in pregnancy: the role of bromocriptine therapy. American Journal of Obstetrics and Gynecology $1990 \mathbf{1 6 3}$ 477-478.

119 Blackhurst G, Strachan MW, Collie D, Gregor A, Statham PF \& Seckl JE. The treatment of a thyrotropin-secreting pituitary macroadenoma with octreotide in twin pregnancy. Clinical Endocrinology $2002 \mathbf{5 7} 401-404$.

120 Boulanger C, Vezzosi D, Bennet A, Lorenzini F, Fauvel J \& Caron P. Normal pregnancy in a woman with nesidioblastosis treated with somatostatin analog octreotide. Journal of Endocrinological Investigation 200427 465-470.

121 Fassnacht M, Capeller B, Arlt W, Steck T \& Allolio B. Octreotide LAR treatment throughout pregnancy in an acromegalic woman. Clinical Endocrinology 200155 411-415.

122 Neal JM. Successful pregnancy in a woman with acromegaly treated with octreotide. Endocrine Practice 20006 148-150.

123 Caron P, Buscail L, Beckers A, Esteve JP, Igout A, Hennen G \& Susini C. Expression of somatostatin receptor SST4 in human placenta and absence of octreotide effect on human placental growth hormone concentration during pregnancy. Journal of Clinical Endocrinology and Metabolism 199782 3771-3776.

124 Takano T, Saito J, Soyama A, Ito H, Iizuka T, Yoshida T \& Nishikawa T. Normal delivery following an uneventful pregnancy in a Japanese acromegalic patient after discontinuation of octreotide long acting release formulation at an early phase of pregnancy. Endocrine Journal 200653 209-212.

125 Caron P, Gerbeau C \& Pradayrol L. Maternal-fetal transfer of octreotide. New England Journal of Medicine 1995333 601-602.

126 de Menis E, Billeci D, Marton E \& Gussoni G. Uneventful pregnancy in an acromegalic patient treated with slow-release lanreotide a case report. Journal of Clinical Endocrinology and Metabolism $1999 \mathbf{8 4} 1489$.

127 Brian SR, Bidlingmaier M, Wajnrajch MP, Weinzimer SA \& Inzucchi SE. Treatment of acromegaly with pegvisomant during pregnancy: maternal and fetal effects. Journal of Clinical Endocrinology and Metabolism 200792 3374-3377.

128 Qureshi A, Kalu E, Ramanathan G, Bano G, Croucher C \& Panahloo A. IVF/ICSI in a woman with active acromegaly: successful outcome following treatment with pegvisomant Journal of Assisted Reproduction and Genetics 200623 439-442.

129 Molitch ME. Pituitary disorders during pregnancy. Endocrinology and Metabolism Clinics of North America 200635 99-116.

130 Lau SL, McGrath S, Evain-Brion D \& Smith R. Clinical and biochemical improvement in acromegaly during pregnancy. Journal of Endocrinological Investigation 200831 255-261.

131 Atmaca A, Dagdelen S \& Erbas T. Follow-up of pregnancy in acromegalic women: different presentations and outcomes. Experimental and Clinical Endocrinology and Diabetes 2006114 $135-139$.

132 Colao A, Merola B, Ferone D \& Lombardi G. Acromegaly. Journal of Clinical Endocrinology and Metabolism $1997 \mathbf{8 2}$ 2777-2781.

133 Cozzi R, Attanasio R \& Barausse M. Pregnancy in acromegaly: a one-center experience. European Journal of Endocrinology 2006 $155279-284$.

134 Arafah BM \& Nasrallah MP. Pituitary tumors: pathophysiology, clinical manifestations and management. Endocrine-Related Cancer 20018 287-305.

135 Casanueva FF, Molitch ME, Schlechte JA, Abs R, Bonert V. Bronstein MD, Brue T, Cappabianca P, Colao A, Fahlbusch R,
Fideleff H, Hadani M, Kelly P, Kleinberg D, Laws E, Marek J, Scanlon M, Sobrinho LG, Wass JA \& Giustina A. Guidelines of the Pituitary Society for the diagnosis and management of prolactinomas. Clinical Endocrinology 200665 265-273.

136 Molitch ME. Pregnancy and the hyperprolactinemic woman. New England Journal of Medicine 1985312 1364-1370.

137 Musolino NRC \& Bronstein MD. Prolactinomas pregnancy. In Pituitary Tumors in Pregnancy, pp 91-108. Ed. MD Bronstein, Boston: Kluwer Academic Publishers, 2001.

138 Heaney AP, Fernando M \& Melmed S. Functional role of estrogen in pituitary tumor pathogenesis. Journal of Clinical Investigation $2002109277-283$.

139 Ciccarelli E \& Camanni F. Diagnosis and drug therapy of prolactinoma. Drugs 199651 954-965.

140 Crosignani PG. Current treatment issues in female hyperprolactinaemia. European Journal of Obstetrics, Gynecology, and Reproductive Biology 2006125 152-164.

141 Bronstein MD, Salgado LR \& Castro Musolino NR. Medical management of pituitary adenomas: the special case of management of the pregnant woman. Pituitary 20025 99-107.

142 Holmgren U, Bergstrand G, Hagenfeldt K \& Werner S. Women with prolactinoma - effect of pregnancy and lactation on serum prolactin and on tumour growth. Acta Endocrinologica 1986111 $452-459$.

143 Kupersmith MJ, Rosenberg C \& Kleinberg D. Visual loss in pregnant women with pituitary adenomas. Annals of Internal Medicine 1994121 473-477.

144 Molitch ME. Management of prolactinomas during pregnancy. Journal of Reproductive Medicine 199944 1121-1126.

145 Brodsky JB, Cohen EN, Brown BW Jr, Wu ML \& Whitcher C. Surgery during pregnancy and fetal outcome. American Journal of Obstetrics and Gynecology 1980138 1165-1167.

146 Griffith RW, Turkalj I \& Braun P. Outcome of pregnancy in mothers given bromocriptine. British Journal of Clinical Pharmacology $19785227-231$.

147 Konopka P, Raymond JP, Merceron RE \& Seneze J. Continuous administration of bromocriptine in the prevention of neurological complications in pregnant women with prolactinomas. American Journal of Obstetrics and Gynecology 1983146 935-938.

148 Krupp P \& Monka C. Bromocriptine in pregnancy: safety aspects. Klinische Wochenschrift 198765 823-827.

149 Turkalj I, Braun P \& Krupp P. Surveillance of bromocriptine in pregnancy. Journal of the American Medical Association 1982247 1589-1591.

150 Raymond JP, Goldstein E, Konopka P, Leleu MF, Merceron RE \& Loria Y. Follow-up of children born of bromocriptine-treated mothers. Hormone Research 198522 239-246.

151 Sam S \& Molitch ME. Timing and special concerns regarding endocrine surgery during pregnancy. Endocrinology and Metabolism Clinics of North America 200332 337-354.

152 Chiodini I \& Liuzzi A. PRL-secreting pituitary adenomas in pregnancy. Journal of Endocrinological Investigation 200326 96-99.

153 Colao A, Abs R, Barcena DG, Chanson P, Paulus W \& Kleinberg DL. Pregnancy outcomes following cabergoline treatment: extended results from a 12-year observational study. Clinical Endocrinology 200868 66-71.

154 Jones J, Bashir T, Olney J \& Wheatley T. Cabergoline treatment for a large macroprolactinoma throughout pregnancy. Journal of Obstetrics and Gynaecology 199717 375-376.

155 Liu C \& Tyrrell JB. Successful treatment of a large macroprolactinoma with cabergoline during pregnancy. Pituitary 2001 4 179-185.

156 Ricci E, Parazzini F, Motta T, Ferrari CI, Colao A, Clavenna A, Rocchi F, Gangi E, Paracchi S, Gasperi M, Lavezzari M, Nicolosi AE, Ferrero S, Landi ML, Beck-Peccoz P \& Bonati M. Pregnancy outcome after cabergoline treatment in early weeks of gestation. Reproductive Toxicology 200216 791-793.

157 Robert E, Musatti L, Piscitelli G \& Ferrari CI. Pregnancy outcome after treatment with the ergot derivative, cabergoline. Reproductive Toxicology 199610 333-337. 
158 Verhelst J \& Abs R. Hyperprolactinemia: pathophysiology and management. Treatments in Endocrinology 20032 23-32.

159 Laloi-Michelin M, Ciraru-Vigneron N \& Meas T. Cabergoline treatment of pregnant women with macroprolactinomas. International Journal of Gynaecology and Obstetrics 200799 61-62.

160 Webster J. A comparative review of the tolerability profiles of dopamine agonists in the treatment of hyperprolactinaemia and inhibition of lactation. Drug Safety 199614 228-238.

161 Morange I, Barlier A, Pellegrini I, Brue T, Enjalbert A \& Jaquet P. Prolactinomas resistant to bromocriptine long-term efficacy of quinagolide and outcome of pregnancy. European Journal of Endocrinology 1996135 413-420.

162 Christin-Maitre S, Delemer B, Touraine $\mathrm{P}$ \& Young J. Prolactinoma and estrogens: pregnancy, contraception and hormonal replacement therapy. Annales d'Endocrinologie 2007 68 106-112.

163 Weil C. The safety of bromocriptine in hyperprolactinaemic female infertility: a literature review. Current Medical Research and Opinion 198610 172-195.

164 Crosignani PG, Mattei AM, Severini V, Cavioni V, Maggioni P \& Testa G. Long-term effects of time, medical treatment and pregnancy in 176 hyperprolactinemic women. European Journal of Obstetrics, Gynecology, and Reproductive Biology 1992 44 175-180.

165 Rasmussen C, Bergh T, Nillius SJ \& Wide L. Return of menstruation and normalization of prolactin in hyperprolactinemic women with bromocriptine-induced pregnancy. Fertility and Sterility 198544 31-34.

166 Bergh T, Nillius SJ \& Wide L. Clinical course and outcome of pregnancies in amenorrhoeic women with hyperprolactinaemia and pituitary tumors. BMJ $1978 \mathbf{1} 875-880$.

167 Chaiamnuay S, Moster M, Katz MR \& Kim YN. Successful management of a pregnant woman with a TSH secreting pituitary adenoma with surgical and medical therapy. Pituitary 20036 109-113.

168 Caron P, Gerbeau C, Pradayrol L, Simonetta C \& Bayard F. Successful pregnancy in an infertile woman with a thyrotropinsecreting macroadenoma treated with somatostatin analog (octreotide). Journal of Clinical Endocrinology and Metabolism 199681 1164-1168.

169 Siristatidis C, Mastorakos G, Vitoratos N, Gregoriou O, Iakovidou H, Salamalekis E \& Creatsas G. Thyroid hormone resistance and enlargement of the sella turcica during pregnancy. Archives of Gynecology and Obstetrics 2004269 152-155.

170 Ghayuri M \& Liu JH. Ovarian hyperstimulation syndrome caused by pituitary gonadotroph adenoma secreting follicle-stimulating hormone. Obstetrics and Gynecology 2007109 547-549.

171 Murata Y, Ando H, Nagasaka T, Takahashi I, Saito K, Fukugaki H, Matsuzawa K \& Mizutani S. Successful pregnancy after bromocriptine therapy in an anovulatory woman complicated with ovarian hyperstimulation caused by folliclestimulating hormone-producing plurihormonal pituitary microadenoma. Journal of Clinical Endocrinology and Metabolism 2003 88 1988-1993.

172 de Heide LJ, van Tol KM \& Doorenbos B. Pituitary apoplexy presenting during pregnancy. Netherlands Journal of Medicine $200462393-396$.

173 Masding MG, Lees PD, Gawne-Cain ML \& Sandeman DD. Visual field compression by a non-secreting pituitary tumour during pregnancy. Journal of the Royal Society of Medicine 2003 $9627-28$.

174 Hayashi M, Tomobe K, Hoshimoto K \& Ohkura T. Successful pregnancy following gonadotropin therapy in a patient with hypogonadotropic hypogonadism resulting from craniopharyngioma. International Journal of Clinical Practice $2002 \mathbf{5 6}$ 149-151.

175 Aydin Y, Can SM, Gulkilik A, Turkmenoglu O, Alatli C \& Ziyal I. Rapid enlargement and recurrence of a preexisting intrasellar craniopharyngioma during the course of two pregnancies. Case report. Journal of Neurosurgery 199991 322-324.
176 Maniker AH \& Krieger AJ. Rapid recurrence of craniopharyngioma during pregnancy with recovery of vision: a case report. Surgical Oncology 199645 324-327.

177 Sachs BP, Smith SK, Cassar J \& Van Iddekinge B. Rapid enlargement of craniopharyngioma in pregnancy. British Journal of Obstetrics and Gynaecology $1978 \mathbf{8 5} 577-578$.

178 Hiett AK \& Barton JR. Diabetes insipidus associated with craniopharyngioma in pregnancy. Obstetrics and Gynecology 199076 982-984.

179 van der Wildt B, Drayer JI \& Eskes TK. Diabetes insipidus in pregnancy as a first sign of a craniopharyngioma. European Journal of Obstetrics, Gynecology, and Reproductive Biology 1980 $10269-274$.

180 Johnson RJ Jr, Voorhies RM, Witkin M, Robichaux AG III \& Broussard WA Jr. Fertility following excision of a symptomatic craniopharyngioma during pregnancy: case report. Surgical Neurology $199339257-262$.

181 Feinberg EC, Molitch ME, Endres LK \& Peaceman AM. The incidence of Sheehan's syndrome after obstetric hemorrhage. Fertility and Sterility 200584 975-979.

182 Abs R, Bengtsson BA, Hernberg-Stahl E, Monson JP, Tauber JP, Wilton P \& Wuster C. GH replacement in 1034 growth hormone deficient hypopituitary adults: demographic and clinical characteristics, dosing and safety. Clinical Endocrinology 1999 $\mathbf{5 0} 703-713$.

183 Engelberth O, Jezkova Z, Bleha O, Malek J \& Bendl J. Autoantibodies in Sheehan's syndrome. Casopis Lekaru Ceskych 1965104108.

184 Goswami R, Kochupillai N, Crock PA, Jaleel A \& Gupta N. Pituitary autoimmunity in patients with Sheehan's syndrome. Journal of Clinical Endocrinology and Metabolism 200287 4137-4141.

185 Nishiyama S, Takano T, Hidaka Y, Takada K, Iwatani Y \& Amino N. A case of postpartum hypopituitarism associated with empty sella: possible relation to postpartum autoimmune hypophysitis. Endocrine Journal 199340 431-438.

186 Patel MC, Guneratne N, Haq N, West TE, Weetman AP \& Clayton RN. Peripartum hypopituitarism and lymphocytic hypophysitis. Quarterly Journal of Medicine 199588 571-580.

187 Otsuka F, Kageyama J, Ogura T, Hattori T \& Makino H. Sheehan's syndrome of more than 30 years' duration: an endocrine and MRI study of 6 cases. Endocrine Journal 199845 451-458.

188 De Bellis A, Kelestimur F, Sinisi AA, Ruocco G, Tirelli G, Battaglia M, Bellastella G, Conzo G, Tanriverdi F, Unluhizarci K, Bizzarro A \& Bellastella A. Anti-hypothalamus and anti-pituitary antibodies may contribute to perpetuate the hypopituitarism in patients with Sheehan's syndrome. European Journal of Endocrinology $2008 \mathbf{1 5 8}$ 147-152.

189 Bakiri F, Bendib SE, Maoui R, Bendib A \& Benmiloud M. The sella turcica in Sheehan's syndrome: computerized tomographic study in 54 patients. Journal of Endocrinological Investigation 199114 193-196.

190 Fleckman AM, Schubart UK, Danziger A \& Fleischer N. Empty sella of normal size in Sheehan's syndrome. American Journal of Medicine 198375 585-591.

191 Sherif IH, Vanderley CM, Beshyah S \& Bosairi S. Sella size and contents in Sheehan's syndrome. Clinical Endocrinology 198930 613-618.

192 Tanriverdi F, Atmaca H, Durak AC, Gokce C, Unluhizarci K, Bayram F \& Kelestimur F. Evaluation of the sella volume in patients with Sheehan's syndrome (Abstract), 12th International Congress of Endocrinology, Lisbon, 2004.

193 Kelestimur F. Sheehan's syndrome. Pituitary 20036 181-188.

194 Ozbey N, Inanc S, Aral F, Azezli A, Orhan Y, Sencer E \& Molvalilar S. Clinical and laboratory evaluation of 40 patients with Sheehan's syndrome. Israel Journal of Medical Sciences 1994 30 826-829.

195 Huang YY, Ting MK, Hsu BR \& Tsai JS. Demonstration of reserved anterior pituitary function among patients with amenorrhea after postpartum hemorrhage. Gynecological Endocrinology 200014 99-104. 
196 Dokmetas HS, Kilicli F, Korkmaz S \& Yonem O. Characteristic features of 20 patients with Sheehan's syndrome. Gynecological Endocrinology 200622 279-283.

197 Dejager S, Gerber S, Foubert L \& Turpin G. Sheehan's syndrome: differential diagnosis in the acute phase. Journal of Internal Medicine $1998244261-266$.

198 Lavallee G, Morcos R, Palardy J, Aube M \& Gilbert D. MR of nonhemorrhagic postpartum pituitary apoplexy. American Journal of Neuroradiology 199516 1939-1941.

199 Vaphiades MS, Simmons D, Archer RL \& Stringer W. Sheehan syndrome: a splinter of the mind. Survey of Ophthalmology 2003 48 230-233.

200 Haddock L, Vega LA, Aguilo F \& Rodriguez O. Adrenocortical, thyroidal and human growth hormone reserve in Sheehan's syndrome. Johns Hopkins Medical Journal 1972131 80-99.

201 Kelestimur F, Jonsson P, Molvalilar S, Gomez JM, Auernhammer CJ, Colak R, Koltowska-Haggstrom M \& Goth MI. Sheehan's syndrome: baseline characteristics and effect of 2 years of growth hormone replacement therapy in 91 patients in KIMS. European Journal of Endocrinology 2005152 581-587.

202 Kelestimur F. GH deficiency and the degree of hypopituitarism. Clinical Endocrinology $199542443-444$.

203 Jialal I, Naidoo C, Norman RJ, Rajput MC, Omar MA \& Joubert SM. Pituitary function in Sheehan's syndrome. Obstetrics and Gynecology 198463 15-19.

204 Shahmanesh M, Ali Z, Pourmand M \& Nourmand I. Pituitary function tests in Sheehan's syndome. Clinical Endocrinology 1980 12 303-311.

205 Kelestimur F. Sheehan's syndrome. In Growth Hormone Deficiency in Adults: 10 Years of KIMS, pp 277-287. Eds R Abs \& U FeldtRasmussen, Oxford, UK: Oxford Pharmagenesis, 2004.

206 Kelestimur F. Hyperprolactinemia in a patient with Sheehan's syndrome. Southern Medical Journal 199285 1008-1010.

207 Stacpoole PW, Kandell TW \& Fisher WR. Primary empty sella, hyperprolactinemia, and isolated ACTH deficiency after postpartum hemorrhage. American Journal of Medicine $1983 \mathbf{7 4}$ 905-908.

208 Kan AK \& Calligerous D. A case report of Sheehan syndrome presenting with diabetes insipidus. Australian and New Zealand Journal of Obstetrics and Gynaecology 199838 224-226.

209 Sheehan HL \& Whitehead R. The neurohypophysis in post-partum hypopituitarism. Journal of Pathology and Bacteriology $1963 \mathbf{8 5} 145-169$.

210 Whitehead R. The hypothalamus in post-partum hypopituitarism. Journal of Pathology and Bacteriology $1963 \mathbf{8 6} 55-67$.

211 Arnaout MA \& Ajlouni K. Plasma vasopressin responses in postpartum hypopituitarism: impaired response to osmotic stimuli. Acta Endocrinologica 1992127 494-498.

212 Atmaca H, Tanriverdi F, Gokce C, Unluhizarci K \& Kelestimur F. Posterior pituitary function in Sheehan's syndrome. European Journal of Endocrinology 2007156 563-567.

213 Dash RJ, Gupta V \& Suri S. Sheehan's syndrome: clinical profile, pituitary hormone responses and computed sellar tomography. Australian and New Zealand Journal of Medicine $19932326-31$.

214 Algun E, Ayakta H, Harman M, Topal C \& Aksoy H. Spontaneous pregnancy in a patient with Sheehan's syndrome. European Journal of Obstetrics, Gynecology, and Reproductive Biology 2003 $110242-244$.

215 Chaieb L, Chadli M, Jemni L, Chatti N, Hidar M, Zebidi A \& Djaidane A. Sheehan's syndrome followed by spontaneous pregnancy. Apropos of 2 cases. Journal de Gynecologie, Obstetrique et Biologie de la Reproduction 198615 765-768.

216 Cohen BL \& Baillie P. Sheehan's syndrome followed by successful pregnancy: a case report. South African Medical Journal 198057 838-840.

217 Colakoglu M, Ercal T \& Karslioglu S. Commencement of normal menstrual cycles after 17 years in a patient with Sheehan's syndrome. American Journal of Medicine $1987 \mathbf{8 2} 578$.
218 Grimes HG \& Brooks MH. Pregnancy in Sheehan's syndrome. Report of a case and review. Obstetrical and Gynecological Survey $198035481-488$.

219 Turksoy RN, Rogers J, Kennison RD \& Finlayson WJ. Spontaneous ovulation and conception after cessation of human gonadotropin therapy in a patient with Sheehan's syndrome. Journal of Reproductive Medicine 19728 299-302.

220 Zargar AH, Masoodi SR, Laway BA, Sofi FA \& Wani AI. Pregnancy in Sheehan's syndrome: a report of three cases. Journal of the Association of Physicians of India $1998 \mathbf{4 6} 476-478$.

221 Sheehan HL. Postpartum necrosis of the anterior pituitary. Effect of subsequent pregnancy. Lancet $19391818-820$.

222 See TT, Lee SP \& Chen HF. Spontaneous pregnancy and partial recovery of pituitary function in a patient with Sheehan's syndrome. Journal of the Chinese Medical Association 200568 187-190.

223 Soares DV, Spina LD, de Lima Oliveira Brasil RR, Lobo PM, Salles E, Coeli CM, Conceicao FL \& Vaisman M. Two years of growth hormone replacement therapy in a group of patients with Sheehan's syndrome. Pituitary 2006 9 127-135.

224 Tanriverdi F, Eryol NK, Atmaca H, Unluhizarci K, Ozdogru I, Sarikaya I, Bayram F \& Kelestimur F. The effects of 12 months of growth hormone replacement therapy on cardiac autonomic tone in adults with growth hormone deficiency. Clinical Endocrinology 200562 706-712.

225 Tanriverdi F, Borlu M, Atmaca H, Koc CA, Unluhizarci K, Utas S \& Kelestimur F. Investigation of the skin characteristics in patients with severe GH deficiency and the effects of 6 months of GH replacement therapy: a randomized placebo controlled study. Clinical Endocrinology 200665 579-585.

226 Ismailogullari S, Tanriverdi F, Kelestimur F \& Aksu M. Sleep architecture in Sheehan's syndrome before and 6 months after growth hormone replacement therapy. Psychoneuroendocrinology $200934212-219$.

227 Rivera JA. Lymphocytic hypophysitis: disease spectrum and approach to diagnosis and therapy. Pituitary 2006 $935-45$.

228 Bellastella A, Bizzarro A, Coronella C, Bellastella G, Sinisi AA \& De Bellis A. Lymphocytic hypophysitis: a rare or underestimated disease? European Journal of Endocrinology $2003149363-376$.

229 Asa SL, Kelly MA, Grandy DK \& Low MJ. Pituitary lactotroph adenomas develop after prolonged lactotroph hyperplasia in dopamine D2 receptor-deficient mice. Endocrinology 1999140 5348-5355.

230 Baskin DS, Townsend JJ \& Wilson CB. Lymphocytic adenohypophysitis of pregnancy simulating a pituitary adenoma: a distinct pathological entity. Report of two cases. Journal of Neurosurgery 198256 148-153.

231 Beressi N, Beressi JP, Cohen R \& Modigliani E. Lymphocytic hypophysitis. A review of 145 cases. Annales de Medecine Interne $1999150327-341$.

232 Hashimoto K, Takao T \& Makino S. Lymphocytic adenohypophysitis and lymphocytic infundibuloneurohypophysitis. Endocrine Journal $1997 \mathbf{4 4} 1-10$.

233 Kidd D, Wilson P, Unwin B \& Dorward N. Lymphocytic hypophysitis presenting early in pregnancy. Journal of Neurology 2003250 1385-1387.

234 Ozbey N, Kahraman H, Yilmaz L, Orhan Y, Sencer E \& Molvalilar S. Clinical course of a pituitary macroadenoma in the first trimester of pregnancy: probable lymphocytic hypophysitis. International Journal of Clinical Practice 199953 478-481.

235 Gal R, Schwartz A, Gukovsky-Oren S, Peleg D, Goldman J \& Kessler E. Lymphoid hypophysitis associated with sudden maternal death: report of a case review of the literature. Obstetrical and Gynecological Survey 198641 619-621.

236 Caturegli P, Newschaffer C, Olivi A, Pomper MG, Burger PC \& Rose NR. Autoimmune hypophysitis. Endocrine Reviews 200526 599-614.

237 Gutenberg A, Hans V, Puchner MJ, Kreutzer J, Bruck W, Caturegli P \& Buchfelder M. Primary hypophysitis: clinicalpathological correlations. European Journal of Endocrinology 2006 155 101-107. 
238 Elias KA \& Weiner RI. Direct arterial vascularization of estrogeninduced prolactin-secreting anterior pituitary tumors. PNAS $1984814549-4553$.

239 O'Dwyer DT, Smith AI, Matthew ML, Andronicos NM, Ranson M, Robinson PJ \& Crock PA. Identification of the 49-kDa autoantigen associated with lymphocytic hypophysitis as alpha-enolase. Journal of Clinical Endocrinology and Metabolism $200287752-757$.

240 O'Dwyer DT, Clifton V, Hall A, Smith R, Robinson PJ \& Crock PA. Pituitary autoantibodies in lymphocytic hypophysitis target both gamma- and alpha-enolase - a link with pregnancy? Archives of Physiology and Biochemistry 2002110 94-98.

241 Watanabe K, Tada H, Shimaoka Y, Hidaka Y, Tatsumi K, Izumi Y \& Amino N. Characteristics of experimental autoimmune hypophysitis in rats: major antigens are growth hormone, thyrotropin, and luteinizing hormone in this model. Autoimmunity 200133 265-274.

242 Buckland RH \& Popham PA. Lymphocytic hypophysitis complicated by post-partum haemorrhage. International Journal of Obstetric Anesthesia 19987 263-266.

243 McCutcheon IE \& Oldfield EH. Lymphocytic adenohypophysitis presenting as infertility. Case report. Journal of Neurosurgery 1991 74 821-826.

244 Portocarrero CJ, Robinson AG, Taylor AL \& Klein I. Lymphoid hypophysitis. An unusual cause of hyperprolactinemia and enlarged sella turcica. Journal of the American Medical Association 1981246 1811-1812.

245 Thodou E, Asa SL, Kontogeorgos G, Kovacs K, Horvath E \& Ezzat S. Clinical case seminar: lymphocytic hypophysitis: clinicopathological findings. Journal of Clinical Endocrinology and Metabolism $1995802302-2311$.

246 Biswas M, Thackare H, Jones MK \& Bowen-Simpkins P. Lymphocytic hypophysitis and headache in pregnancy. British Journal of Obstetrics and Gynaecology 2002109 1184-1186.

247 Imura H, Nakao K, Shimatsu A, Ogawa Y, Sando T, Fujisawa I \& Yamabe H. Lymphocytic infundibuloneurohypophysitis as a cause of central diabetes insipidus. New England Journal of Medicine 1993329 683-689.

248 Leggett DA, Hill PT \& Anderson RJ. 'Stalkitis' in a pregnant 32-year-old woman: a rare cause of diabetes insipidus. Australasian Radiology 199943 104-107.

249 Leung GK, Lopes MB, Thorner MO, Vance ML \& Laws ER Jr. Primary hypophysitis: a single-center experience in 16 cases. Journal of Neurosurgery $2004101262-271$.

250 Bensing S, Hulting AL, Hoog A, Ericson K \& Kampe O. Lymphocytic hypophysitis: report of two biopsy-proven cases and one suspected case with pituitary autoantibodies. Journal of Endocrinological Investigation 200730 153-162.

251 Karaca Z, Tanriverdi F, Donmez H, Unluhizarci K \& Kelestimur F. Empty sella may be the final outcome in lymphocytic hypophysitis. Endocrine Research 200934 10-17.

252 Klein J \& Fehm HL. Unusual presentation of hypophysitis preceding an empty sella in a 75 -year-old woman. Neuroendocrinology Letters 200526 757-758.

253 Unluhizarci K, Bayram F, Colak R, Ozturk F, Selcuklu A, Durak AC \& Kelestimur F. Distinct radiological and clinical appearance of lymphocytic hypophysitis. Journal of Clinical Endocrinology and Metabolism 200186 1861-1864.

254 De Marinis L, Bonadonna S, Bianchi A, Maira G \& Giustina A. Primary empty sella. Journal of Clinical Endocrinology and Metabolism 200590 5471-5477.

255 Brandes JC \& Cerletty JM. Pregnancy in lymphocytic hypophysitis: case report and review. Wisconsin Medical Journal $1989 \mathbf{8 8}$ 29-32.

256 Gagneja H, Arafah B \& Taylor HC. Histologically proven lymphocytic hypophysitis: spontaneous resolution and subsequent pregnancy. Mayo Clinic Proceedings 199974 150-154.

257 Sinha D, Sinha A \& Pirie AM. A case of recurrent lymphocytic hypophysitis in pregnancy. Journal of Obstetrics and Gynaecology $200626255-256$.
258 Verdu LI, Martin-Caballero C, Garcia-Lopez G \& Cueto MJ. Ovulation induction and normal pregnancy after panhypopituitarism due to lymphocytic hypophysitis. Obstetrics and Gynecology $199891850-852$.

259 Reusch JE, Kleinschmidt-DeMasters BK, Lillehei KO, Rappe D \& Gutierrez-Hartmann A. Preoperative diagnosis of lymphocytic hypophysitis (adenohypophysitis) unresponsive to short course dexamethasone: case report. Neurosurgery 199230 268-272.

260 Magyar DM \& Marshall JR. Pituitary tumors and pregnancy. American Journal of Obstetrics and Gynecology $1978 \mathbf{1 3 2}$ 739-751.

261 van der Spuy ZM \& Jacobs HS. Management of endocrine disorders in pregnancy. Part II. Pituitary, ovarian and adrenal disease. Postgraduate Medical Journal 198460 312-320.

262 Overton CE, Davis CJ, West C, Davies MC \& Conway GS. High risk pregnancies in hypopituitary women. Human Reproduction 2002 17 1464-1467.

263 Hall R, Manski-Nankervis J, Goni N, Davies MC \& Conway GS. Fertility outcomes in women with hypopituitarism. Clinical Endocrinology 200665 71-74.

264 Homburg R, Eshel A, Armar NA, Tucker M, Mason PW, Adams J, Kilborn J, Sutherland IA \& Jacobs HS. One hundred pregnancies after treatment with pulsatile luteinising hormone releasing hormone to induce ovulation. BMJ 1989298 809-812.

265 Tsilchorozidou T \& Conway GS. Uterus size and ovarian morphology in women with isolated growth hormone deficiency, hypogonadotrophic hypogonadism and hypopituitarism. Clinical Endocrinology $200461567-572$.

266 de Boer JA, Schoemaker J \& van der Veen EA. Impaired reproductive function in women treated for growth hormone deficiency during childhood. Clinical Endocrinology 199746 681-689.

267 Homburg R, Levy T \& Ben Rafael Z. Adjuvant growth hormone for induction of ovulation with gonadotrophin-releasing hormone agonist and gonadotrophins in polycystic ovary syndrome: a randomized, double-blind, placebo controlled trial. Human Reproduction 199510 2550-2553.

268 Tarlatzis BC, Zepiridis L, Grimbizis G \& Bontis J. Clinical management of low ovarian response to stimulation for IVF: a systematic review. Human Reproduction Update 20039 61-76.

269 Muller J, Starup J, Christiansen JS, Jorgensen JO, Juul A \& Skakkebaek NE. Growth hormone treatment during pregnancy in a growth hormone-deficient woman. European Journal of Endocrinology 1995132 727-729.

270 Curran AJ, Peacey SR \& Shalet SM. Is maternal growth hormone essential for a normal pregnancy? European Journal of Endocrinology 1998139 54-58.

271 Hall K, Enberg G, Hellem E, Lundin G, Ottosson-Seeberger A, Sara V, Trygstad O \& Ofverholm U. Somatomedin levels in pregnancy: longitudinal study in healthy subjects and patients with growth hormone deficiency. Journal of Clinical Endocrinology and Metabolism 198459 587-594.

272 Verhaeghe J, Bougoussa M, Van Herck E, de Zegher F, Hennen G \& Igout A. Placental growth hormone and IGF-I in a pregnant woman with Pit-1 deficiency. Clinical Endocrinology 200053 645-647.

273 Giampietro A, Milardi D, Bianchi A, Fusco A, Cimino V, Valle D, Marana R, Pontecorvi A \& De Marinis L. The effect of treatment with growth hormone on fertility outcome in eugonadal women with growth hormone deficiency: report of four cases and review of the literature. Fertility and Sterility 2009 91 930.e7-930.e11.

274 Wiren L, Boguszewski CL \& Johannsson G. Growth hormone (GH) replacement therapy in GH-deficient women during pregnancy. Clinical Endocrinology 200257 235-239.

275 Minneci PC, Deans KJ, Banks SM, Eichacker PQ \& Natanson C. Meta-analysis: the effect of steroids on survival and shock during sepsis depends on the dose. Annals of Internal Medicine 2004141 $47-56$. 
276 Suri D, Moran J, Hibbard JU, Kasza K \& Weiss RE. Assessment of adrenal reserve in pregnancy: defining the normal response to the adrenocorticotropin stimulation test. Journal of Clinical Endocrinology and Metabolism 200691 3866-3872.

277 Diederich S, Eigendorff E, Burkhardt P, Quinkler M, Bumke-Vogt C, Rochel M, Seidelmann D, Esperling P, Oelkers W \& Bahr V. 11ß-Hydroxysteroid dehydrogenase types 1 and 2: an important pharmacokinetic determinant for the activity of synthetic mineralo- and glucocorticoids. Journal of Clinical Endocrinology and Metabolism 200287 5695-5701.

278 Crown A \& Lightman S. Why is the management of glucocorticoid deficiency still controversial: a review of the literature. Clinical Endocrinology 200563 483-492.

279 Arlt W \& Allolio B. Adrenal insufficiency. Lancet $2003 \mathbf{3 6 1}$ 1881-1893.

280 Trainer PJ. Corticosteroids and pregnancy. Seminars in Reproductive Medicine 200220 375-380.

281 McKenzie SA, Selley JA \& Agnew JE. Secretion of prednisolone into breast milk. Archives of Disease in Childhood $1975 \mathbf{5 0}$ 894-896.

282 LaFranchi S. Thyroid hormone in hypopituitarism, Graves' disease, congenital hypothyroidism, and maternal thyroid disease during pregnancy. Growth Hormone $\mathcal{E}$ IGF Research $20061620-24$.

283 LaFranchi SH, Haddow JE \& Hollowell JG. Is thyroid inadequacy during gestation a risk factor for adverse pregnancy and developmental outcomes? Thyroid 200515 60-71.

284 Durr JA. Diabetes insipidus in pregnancy. American Journal of Kidney Diseases $19879276-283$.

285 Kallen BA, Carlsson SS \& Bengtsson BK. Diabetes insipidus and use of desmopressin (Minirin) during pregnancy. European Journal of Endocrinology 1995132 144-146.
286 Ray JG. DDAVP use during pregnancy: an analysis of its safety for mother and child. Obstetrical and Gynecological Survey $1998 \mathbf{5 3}$ 450-455.

287 Hague WM. Pre-existing endocrine disease in relation to pregnancy. Current Obstetrics \& Gynaecology $1999962-68$.

288 Hamai Y, Fujii T, Nishina H, Kozuma S, Yoshikawa H \& Taketani Y. Differential clinical courses of pregnancies complicated by diabetes insipidus which does, or does not, pre-date the pregnancy. Human Reproduction 199712 1816-1818.

289 Kalelioglu I, Kubat UA, Yildirim A, Ozkan T, Gungor F \& Has R. Transient gestational diabetes insipidus diagnosed in successive pregnancies: review of pathophysiology, diagnosis, treatment, and management of delivery. Pituitary 2007 10 87-93.

290 Kennedy S, Hall PM, Seymour AE \& Hague WM. Transient diabetes insipidus and acute fatty liver of pregnancy. British Journal of Obstetrics and Gynaecology 1994101 387-391.

291 Yamanaka Y, Takeuchi K, Konda E, Samoto T, Satou A, Mizudori M \& Maruo T. Transient postpartum diabetes insipidus in twin pregnancy associated with HELLP syndrome. Journal of Perinatal Medicine 200230 273-275.

292 Campo S, Campo V \& Lanzone A. Twin pregnancy using recombinant gonadotropins in a woman with hypogonadotropic hypogonadism. Gynecological Endocrinology 200216 27-32.

293 Dragojevic S, Pazin V, Rakic S, Nikolic B \& Jovanovic T. Pregnancy using gonadotropins and performing intrauterine insemination in a woman with hypogonadotropic hypogonadism. American Journal of Reproductive Immunology $2006 \mathbf{5 5}$ 164-167.

Received 19 November 2009

Accepted 23 November 2009 